INTER NATIONAL MONETARY FUND
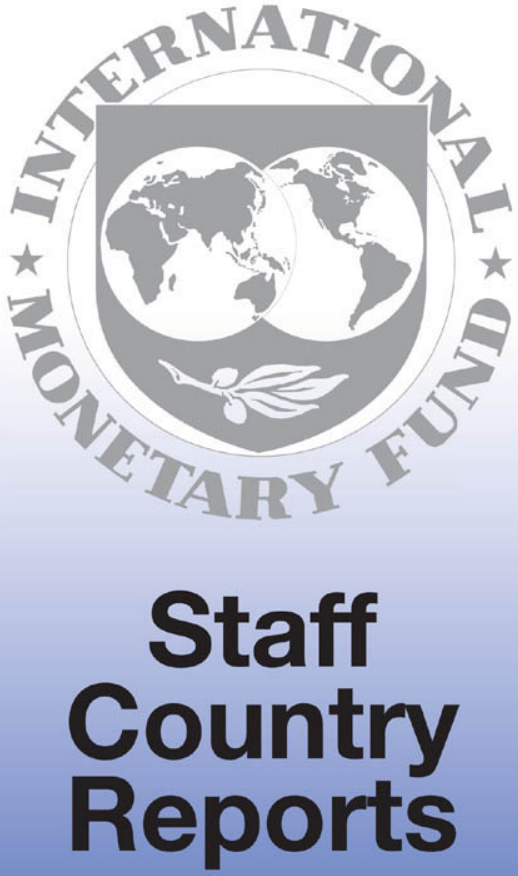


\section{Greece: 2003 Article IV Consultation-Staff Report; Staff Statement; Public Information Notice on the Executive Board Discussion; and Statement by the Executive Director for Greece}

Under Articie IV of the IMF's Articles of Agreement, the IMF holds bilateral discussions with members, usually every year. In the context of the Article IV consultation with Greece, the following documents have becn relcased and are included in this package:

- the staff report for the 2003 Article IV consultation, prepared by a staff team of the IMF, following discussions that ended on February 10, 2003, with the officials of Greece on economic developments and policies. Based on information available at the time of these discussions, the staff report was completed on April 24, 2003. The views cxpressed in the staff report are those of the staff team and do not necessarily reflect the views of the Executive Board of the IMF

- a staff statement of May 16, 2003 updating information on recent developments.

- a Public Information Notice (PIN) summarizing the views of the Executive Board as expressed during its May 16, 2003 discussion of the staff report that concluded the Article IV consultation.

- a statcment by the Executive Director for Greece.

The documents listed below have been or will be separately released.

Selected Issues Paper

Update to the Report on the Observance of Standards and Codes

The policy of publication of staff reports and other documents allows for the deletion of market-sensitivc information.

To assist the IMF in evaluating the publication policy, reader comments are invited and may be sent by e-mail to Publicationpolicy@imforg.

Copies of this report are available to the public from

International Monetary Fund • Publication Services

$70019^{\text {th }}$ Street, N.W. - Washington, D.C. 20431

Telephone: (202) 623-7430 • Telefax: (202) 623-7201

E-mail: publications@imf.org Internet: http://www.imf.org

Price: $\$ 15.00$ a copy

International Monetary Fund

Washington, D.C. 


\section{INTERNATIONAL MONETARY FUND}

\section{GREECE}

\section{Staff Report for the 2003 Article IV Consultation \\ Prepared by the Staff Representatives for the 2003 Consultation with Greece}

Approved by Alessandro Leipold and Liam P. Ebrill

April 24, 2003

- The Article IV discussions were held during January 30-February 10, 2003. The mission-comprising Messrs. Krueger, Billmeier, Lutz, and Vamvakidis (all European I)-met with the Governor of the Bank of Greece; the Ministers of Economy and Finance and of Health; other senior government officials; representatives of the parliamentary opposition, regulatory agencies, labor and business organizations; and academics. Mr. Vittas, Alternate Executive Director, participated in some of the meetings.

- Greece has accepted the obligations of Article VIII, Sections 2, 3, and 4 and maintains an exchange system free of restrictions, apart from those related to UN resolutions (Appendix I).

- For Directors' conclusions at the last Article TV consultation on February 22, 2002, see http://www imf.org/external/np/sec/pn/2002/pn0221 htm. 


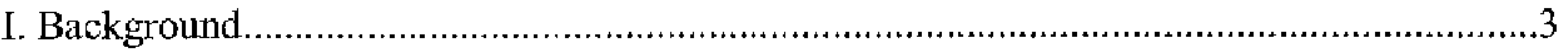

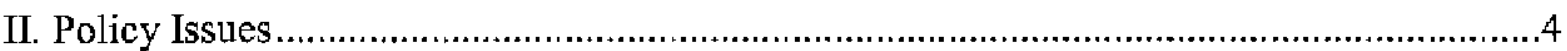

A. Economic Outlook ................................................................................. 5

B. Emerging Mactoeconomic Risks and Policy Exigencies................................6

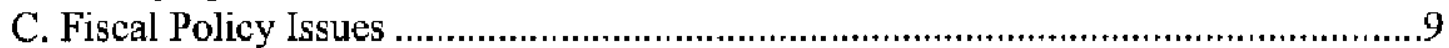

D. Labor and Product Markets ..................................................................... 15

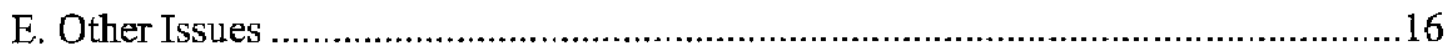

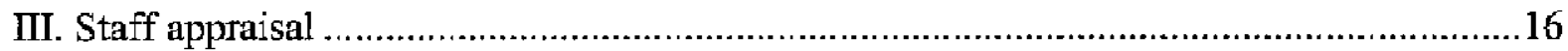

Tables

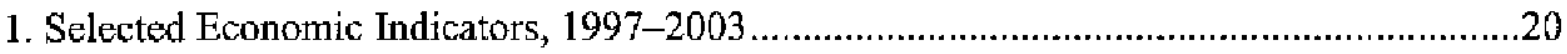

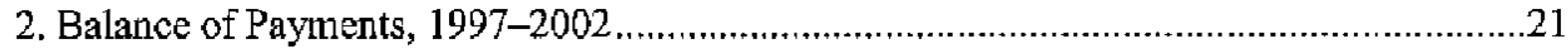

3. Stability and Growth Program and Staff's Medium-Term Scenario, 2002-08 ................22

4. Indicators of External and Financial Vulnerability, 1997-2003 ...............................23

5. Summary of General Govermment Accounts, 1997-2003 .......................................24

Figures

1. International Comparisons of Macroeconomic Performance, 1995-2003 …..................25

2. GDP Growth and Components' Contributions, 1995-2002 .....................................26

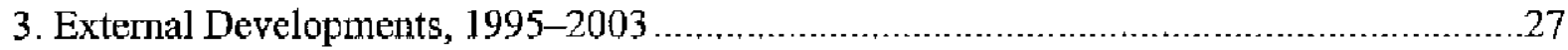

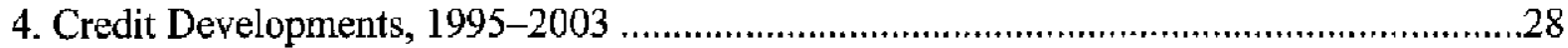

5. Entering Monetary Union-A Comparison of Monetary Conditions and Output .............29

6. Asset Market Developments, 1995-2003 ...........................................................30

7. General Government Deficit Changes and Contributing Factors, 1995-2002 .................31

Boxes

1. Policy Recommendations and Implementation ......................................................4

2. Fiscal Accounting Revisions.............................................................................10

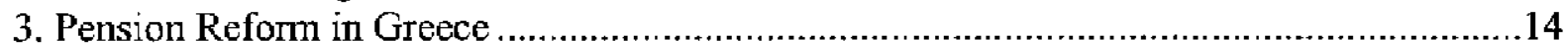

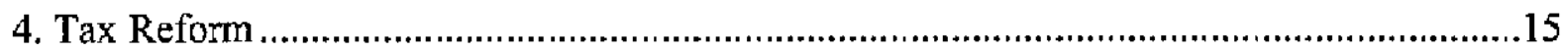

Appendices

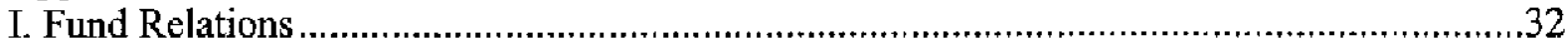

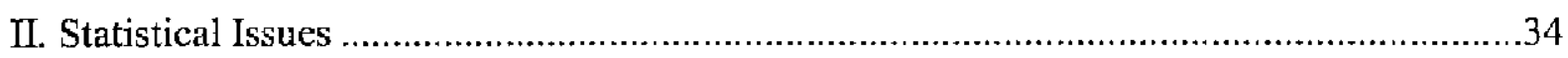

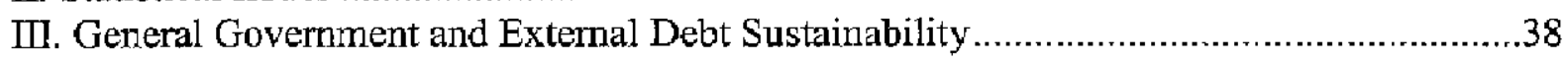




\section{BACKGROUND}

1. The economic expansion that began in the mid-1990s continued unabated in 2002 (Table 1; and Figures 1-2). At 4 percent, GDP growth remained well above the EU average, as an acceleration of domestic demand counterbalanced the slowdown in partner countries. High capacity utilization, EU transfers, and preparations for the 2004 Olympics underpinned investment, while private consumption benefited from sizable increases in household incomes. A relatively loose policy mix added to demand pressures: the fiscal deficit narrowed only marginally, while historically low interest rates resulted in very accommodative monetary

Sclected Economic Indicators, 1999-2003

(Period average in percent, unless otherwise indicated)

\begin{tabular}{|c|c|c|c|c|c|c|}
\hline & \multicolumn{2}{|c|}{ 1999-2001 } & \multicolumn{2}{|c|}{2002} & \multicolumn{2}{|c|}{2003} \\
\hline & Greace & Euto arta & Griect & Eura area & Greece & Euro area \\
\hline Real GDP growth & 4.0 & 2.8 & 4.0 & 0.8 & 3.6 & 1.1 \\
\hline Ouppat gap l/ & 1.6 & -0.1 & 1.9 & -1.4 & 20 & -2.5 \\
\hline Employment gowth & -0.4 & 2.8 & 1,0 & 0.4 & 0.6 & 0.3 \\
\hline IEdation (HICP) & 2.9 & 2.0 & 3.9 & 7.3 & 3.8 & 2.0 \\
\hline $\begin{array}{l}\text { Cumrent acoounst } \\
\text { (in percent of GDP) }\end{array}$ & -5.7 & -0.5 & -6.1 & 0.8 & -6.9 & 3.0 \\
\hline
\end{tabular}

Sources: National Statistical Service; and IMF, WEO databose.

1/ In percent of potentid ODP.

conditions. The latter and recent financial liberalization contributed to rapid credit growth, thereby supporting both investment and consumption. Continued strong ontput growth led, for the first time in four years, to an increase in employment in 2002; the unemployment rate declined but, at 9.7 percent in the last quarter, was still among the highest in the euro area.

\section{Inflation has remained well above the euro-area average and competitiveness} has weakened since Greece entered the euro area in 2001. At around 2 percentage points, the inflation differential vis-à-vis the euro area reflected foremost relatively high labor cost increases in Greece. Staff estimates attribute about balf (and the authorities somewhat less) of the differential to Balassa-Samuelson effects; divergent cyclical positions also played an important role, with a sizable positive output gap estimated for Greece. Since relatively high wage increases ${ }^{1}$ were not fully compensated for by productivity gains, cost and price competitiveness have weakened vis-à-vis the euro area since 2000 , and more recently also vis-à-vis other countries as the euro appreciated.

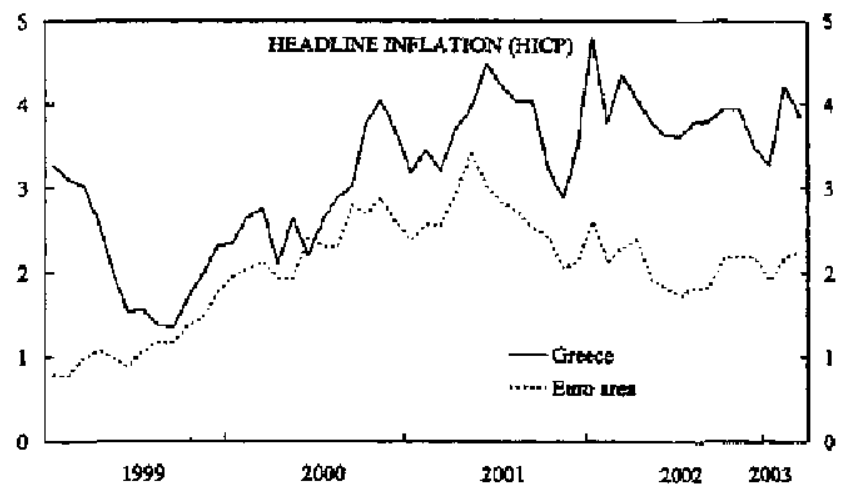

3. The external current account deficit has remained one of the highest (in relation to GDP) among industrial countries. Exports continued to lose market shares in 2002 and

\footnotetext{
${ }^{1}$ A two-year wage agreement called for increases in minimum wages by 5.4 percent in 2002 and 5.1 percent in 2003 (including catch-up clauses for inflation above target of 1.1 percent and 0.3 percent for 2002 and 2003, respectively).
} 
the current account deficit was again above 6 percent of GDP (Table 2; and Figure 3). The deficit was predominantly financed by foreign purchases of euro-denominated government bonds-while FDI inflows remained very small and were outweighed by outflows, as Greek companies expanded into neighboring regions.

\section{Policy Issues}

4. Against the background of strong economic growth in recent years, accompanied by a relatively loose policy mix, the discussions focused on policies to address widening macroeconomic imbalances and lay the foundation for sustainable strong growth, further developing past IMF recommendations (Box 1):

\section{Box 1. Policy Recommendations and Implementation}

The Fund's advice has focused in recent years on policies to advance fiscal consolidation, address potential financial sector risks, and remove structural impediments that limit longer-run growth prospects.

On fiscal policy, the Fund called for a more ambitious fiscal stance than envisaged in recent budget targets, while the authorities argued that a tighter stance would unduly weaken growth, while also being politically difficult to implement. There have also been sizable expenditure overruns and slippages from original budget targets, and the debt ratio has failed to decline appreciably. Success in securing structural fiscal reforms, urged by the Fund, has been mixed, and the present report discusses a recent pension reform that largely fails to rein-in Greece's exceptionally high increases in future pension expenditures.

In light of rapid credit growth, the Fund has wetcomed the authorities' actions to improve banks' risk management and internal control systems. Suggestions for better coordination among the various financial sector supervisors are being addressed, although adequate oversight of the insurance sector remains an issue.

On structural policies, an extensive privatization program continues to be implemented. Efforts to ease administrative hurdles are also proceeding, afthough much remains to be done. In the labor market, little progress was made in addressing the dearth of employment growth and low participation rates, which remain well below Lisbon targets.

- Fiscal consolidation and reform. The authorities stressed the adverse growth impact of rapid fiscal consolidation, but agreed on the need for improving expenditure control and fiscal transparency. The staff argued for stronger fiscal consolidation than envisaged in the 2002-06 Stability Program-in view of Greece's high public debt ratio, fast economic growth, and the need to rein-in the sizable external current account deficit. Moreover, large aging-related spending pressures needed to be addressed with further reforms.

- Measures to safeguard the financial sector. It was agreed that rapid credit growth in the recently liberalized banking sector required added supervisory vigilance, and staff cautioned that evolving risks may warrant over time a strengthening of banks' capital. The 
Bank of Greece had already increased provisioning requirements, and was reviewing the case for expanding disclosure requirements to strengthen market-based discipline.

- Structural reforms to increase employment and sustain strong growth. The authorities were more confident than staff that conditions were in place for strong economic growth over the medium term. They agreed on the case for further privatization and for steps to further reduce administrative investment hurdles. Staff argued that the lack of substantive employment gains in recent years underscored the need for further labor market reform.

5. General elections must be held by April 2004. Following the successful policy effort to enter monetary union, the discussions revealed considerable adjustment fatigueand the run-up to the general elections and uncertainties about the global economic outlook also weighed on prospects for reforms.

\section{A. Economic Outlook}

6. There was agreement that strong, domestic-demand led growth was likely to continue in 2003-04. The authorities expected GDP growth to average close to 4 percent during the next two years: investment was to remain the main engine of growth, and private consumption would be buoyed by further employment gains and a rise in disposable incomes, including from a tax reform. With continued strong growth, inflation was projected to stay at close to 4 percent in 2003, well above the euro-area average. The staff largely agreed with the growth and inflation outlook at the time of the mission, but subsequently revised its 2003 GDP growth forecast down to $3 \frac{1}{2} 2$ percent, in light of more recent indicators.

7. The outlook was subject to large external risks. An extended fallout from the war in Iraq could in particular affect the tourism sector, where receipts had declined somewhat in the aftermath of the 1991 war. The authorities also expressed concerns about the recovery prospects in major export markets and a further appreciation of the euro-to which Greece was particularly vulnerable due to its high and rising export share with countries outside the euro area (see text table). On the upside, a quick resolution of global tensions and falling oil prices could result in a stronger-than-anticipated rebound in foreign demand and strengthen domestic consumption.

Greece: Distribution of Exports, 1990-2001 (Persent of total)

\begin{tabular}{cccc}
\hline & 1990 & 1995 & 2001 \\
\hline Industrial countries & 77.9 & 67.7 & 52.2 \\
Of which: EU & 68.1 & 61.2 & 43.1 \\
Other colmitris & 22.1 & 32.3 & 47.8 \\
Ofwhich: Burse & 10.9 & 20.8 & 35.2 \\
\hline
\end{tabular}

Sources: IMF DCT Statistics; and Fund steff calculations.

8. Views differed to some extent on the growth prospects over the medium term. The Stability Program projects real GDP growth to remain above $3 \frac{1}{2}$ percent (Table 3), supported by recent infrastructure investment and continued strong tourism activity after the Olympics. Staff cautioned, however, that the recent high growth rates may in part reflect temporary, euro-entry related effects-even if these effects seemed longer-lasting than anticipated in last year's report. In any case, there was agreement that growth prospects could benefit greatly from further structural reforms, discussed below. 


\section{B. Emerging Macroeconomic Risks and Policy Exigencies}

9. The experience of other countries indicates that rapid credit growth in the wake of falling interest rates and financial liberalization as well as large current account deficits entail potential macroeconomic risks. The discussions focused on the factors behind these trends in Greece and on policy implications.

\section{Sizable external current account imbalances: policies to strengthen competitiveness}

10. The authorities attributed the widening of the external current account deficit foremost to temporary factors related to monetary union. Since the mid-1990s, the deficit had increased by about 4 percentage points to over 6 percent of GDP in 2002 (see text chart). In terms of the saving-investment balance, this reflected a sharp rise in investment-and the authorities pointed to declining interest rates and the strengthened policy framework in the context of monetary union as the key contributing factors. ${ }^{2}$ Moreover, divergent cyclical conditions were agreed to have temporarily worsened Greece's current account.

11. The staff cautioned, however, that weaknesses in export performance and competitiveness could result in persistent large external deficits, adding to already high levels of foreign indebtedness. For a second year, exports were estimated to bave declined in 2002, as competitiveness indicators continued to weaken. ${ }^{3}$ While an investment (rather than consumption) boom was principally behind the deterioration of the external current account, the authorities concurred that some of the new investment, including rising outlays for infrastructure, had uncertain payoffs in terms of future

Greece's external current account, as in Portugal, increased markedly in the run-up to monetary union

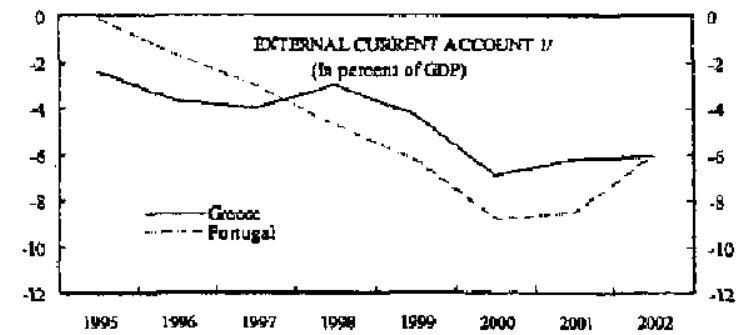

.. with the increase in Greece reflecting higher investment

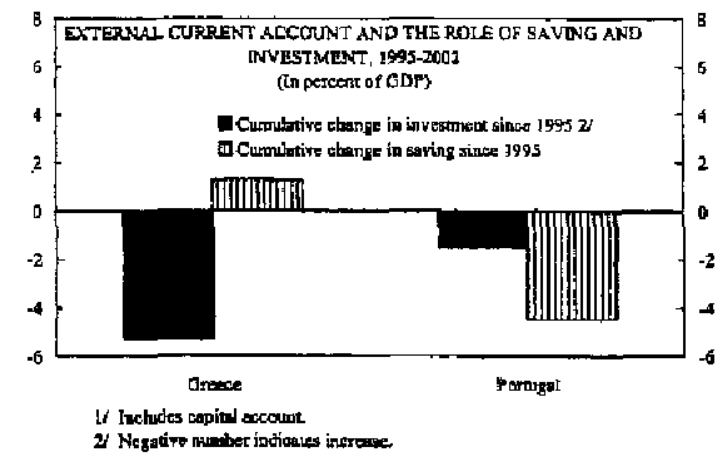

${ }^{2}$ O. Blanchard and F. Giavazzi, "Current Account Deficits in the Euro Area: The End of the Feldstein-Horioka Puzzle?" Brookings Paper on Economic Activity (2002:2), pp. 147-209, also stress the effect of capital and goods market integration on the extemal current account.

${ }^{3}$ External trade and service data have to be interpreted with caution, as they are unusually erratic in Greece and suffer from statistical weaknesses (Appendix II). 
export capacity. Taking these factors into account, staff's analysis (elaborated in a selected issues paper to this report) indicated that, absent policy adjustments, the current account deficit was likely to remain one of the largest among industrial countries, adding to Greece's relatively high level of net external indebtedness (above 40 percent of GDP at end-2001). Increased competition from the EU accession countries and a likely decline in EU structural funds after the end of the present program (2006) could further weaken the extemal accounts. Staff noted that without gains in competitiveness, correcting the current account deficits would entail a prolonged period of weak domestic demand growth. Moreover, the large deficits left the economy exposed to interest rate and refinancing risks (Appendix III), although these were clearly diminished within monetary union.

\section{Concerning policy implications, the authoritles stressed steps to avoid a further} erosion of competitiveness-while staff saw a need to strengthen competitiveness from current levels. Wage moderation had to play a central role to secure adequate cost competitiveness. The authorities saw some risk that recent wage developments were not consistent with this role, and staff emphasized that public sector wages, in contrast to the past, needed to take the lead. Trade union representatives noted, however, the relatively low level of wages in Greece, and were also unconvinced by staff's call to eliminate backwardlooking wage indexation in future wage agreements. Beyond wage policy, the authorities noted that price competitiveness would benefit from increasing competition in some sectors, and they agreed that raising public sector saving could narrow the current account imbalance.

\section{Rapid credit growth and financial sector risks: measures to safeguard the sector}

\section{Household and enterprise indebtedness-still low by international standards-} have risea rapidly in recent years. Euro-entry-related declines in interest rates contributed importantly to strong credit growth (Figures 4-5), and the authorities agreed that monetary conditions were considerably easier than warranted by domestic considerations. The release of blocked excess reserves of banks (see last year's Country Report) also contributed to the credit expansion, and private sector credit has almost doubled in relation to GDP over the past four years (see text table). While private sector credit decelerated somewhat in 2002, mortgage lending continued to grow in excess of 30 percent and contributed to considerable property price increases (Figure 6).

\begin{tabular}{lcc}
\multicolumn{3}{c}{$\begin{array}{c}\text { Private Sector Credit } \\
\text { (In percent of GDP) }\end{array}$} \\
\hline & 2002 & $\begin{array}{c}\text { Chenge } \\
1998-2002\end{array}$ \\
\hline Greece & 52.3 & 93.1 \\
Poutugal & 147.7 & 86.0 \\
Ireland & 110.6 & $102.42 /$ \\
Spain & 114.4 & 73.72 \\
Euro area & 89.3 & 30.5 \\
\hline
\end{tabular}

Sources; IMF, IFS and FLO; Bank of Greece; Central Bark of Irehelon and ECB. L/Cumnlaciva nominal growth since December 1998. U/ Since Janoary 1999 . 
14. Indicators of financial institutions' profitability have weakened recently, in the case of banks from generally high levels (Table 4). Bank profitability and capital adequacy declined substantially from their peak in 1999, when they were driven by exceptional circumstances (including the stock market boom and capital gains on bond holdings as interest rates converged in the run-up to euro-area entry). Moreover, personnel cost indicators remain well above the EU average, notwithstanding recent reductions. Nonperforning loans (NPL) have generally followed a declining trend, and the Greek Commercial Banks, Selected Indicators: 1997-2002 authorities attributed their still high level primarily to ongoing restructuring at one state bank, and to protracted bankruptcy procedures that undermined timely NPL resolution. Supervisors also noted a marked deterioration of financial performance in the insurance sector, mirroring in part international trends. (hi peqcent)

\begin{tabular}{|c|c|c|c|c|c|c|}
\hline & 1997 & โ998 & 1999 & 2000 & 2001 & 2002 \\
\hline Return on asects (after taxes) & 0.? & 0.7 & 2.4 & 1,4 & 1.0 & 0.5 \\
\hline Average in the rest of the euro area $U /$ & 0.5 & 0.5 & 0.5 & 0.6 & 0.9 & ... \\
\hline Returh on equity (after takes) & 13.9 & 13.7 & 28.6 & 15.4 & 12.4 & 6.8 \\
\hline Staff costs (percent of assets) & 1.9 & 1.7 & 1.7 & 13 & 2.4 & $\ldots$ \\
\hline Average in the rest of the curv aren $y$ & 0.9 & 0.8 & 0.8 & 0.8 & 0.8 & $\ldots$ \\
\hline Capital adequacy mita (consolidated basis) & 10.3 & 10.2 & 16.2 & 13.6 & 12.5 & 11.62 \\
\hline Tier I capital adequacy ratio & 9.4 & 9.7 & 15.3 & 13.5 & 10.9 & 10.42 \\
\hline Average in the rest of the euro area $y$ & 7.4 & 7.6 & 7.8 & 7.6 & 7.7 & $\ldots$ \\
\hline Nompariorming loan ratio & 16.5 & 13.6 & 19.5 & 123 & 9.2 & 8.1 \\
\hline Provlatons/norpefforming loans & 19.0 & 24.1 & 26.1 & 36.8 & 43.3 & 45.3 \\
\hline
\end{tabular}

Sources: Bank of Greere; Maodyls, and OECD.

1/ Unwtichted average.

2) Scptember 2002 .

\section{Against this background, the authorities agreed that evolving financial sector} risks warranted added supervisory vigilance, and the discussions focused on:

- Capital adequacy and provisions: the Bank of Greece considered capital and provisions as fully adequate to address potential risks - but acknowledged that the fast pace of credit expansion had raised the risks for the newly liberalized sector, which had not yet experienced an economic downturn. As an indication af continued supervisory vigilance, the Bank noted recent increases in provisioning requirements for NPLs and for loans with limited collateral, and the recruitment of additional personnel to upgrade supervisory expertise (e.g., for assessing banks' risk and provisioning models). Supervisors also stressed that capital ratios, while declining, had remained above levels in many EU countries. Staff cautioned that this seemed warranted by the rapid credit expansion and by the relatively small size of the domestic market and banking institutions; indeed, capital ratios for the main Greek banks were in line with those of similar-sized banks in the EU. Supervisors emphasized that they would continue to assess if evolving risks warranted additional capital and provisioning, and took note of staff's suggestion to review these and other financial sector issues in the context of a Financial Sector Assessment Program (FSAP).

- Disclosure of financial indicators: There was a consensus that timely public disclosure of financial sector information was critical for market-based discipline, and that disclosure requirements in Greece were relatively limited (for example, concerning NPLs and loan concentrations). Banking representatives noted, however, that larger banks already published more information than required; and transparency would also improve with the adoption of international accounting standards in 2003 (see below). Nevertheless, the authorities would consider staff's suggestion for expanding disclosure requirements. 
- Strengthen supervision in the insurance sector and supervisory coordination: The Greek insurance sector is relatively small, comprising about 5 percent of financial sector assets. While no timely data were available, the supervisor thought that solvency ratios of several companies bad fallen below regulatory minima in 2002 . The authorities intended to accelerate reporting requirements and were planning to grant the supervisory agency, which is presently part of the Ministry of Development, full independence. It was also agreed that the demands of increasingly integrated financial markets called for strengthening formal coordination among all financial market supervisors.

\section{Fiscal Policy Issues}

16. Fiscal policy discussions focused on the pace of consolidation and on measures to increase public sector efficiency. Notwithstanding important differences concerning the timing and extent of some policy actions, there was agreement on the general direction: advancing fiscal consolidation to address emerging macroeconomic imbalances and ensure a sizable reduction of the high public debt; securing public expenditure restraint and implementing tax reforms; and improving public sector efficiency and raising accountability.

\section{Fiscal consolidation}

17. Progress on fiscal consolidation has been limited in recent years and public debt remains one of the highest (in relation to GDP) among euro-area countries. Following sizable accounting revisions (that replaced earlier reported small surpluses with deficits; Box 2) and some slippages, the fiscal deficit declined marginally in 2002, to 1.2 percent of GDP. With overruns on current noninterest expenditures, including for wages, a widening of the deficit was only prevented by two temporary factors: unbudgeted revenues of 0.6 percent of GDP from a tax amnesty (i.e., the settlement of tax arrears for the self-employed); and lower-than-budgeted investment spending, related in part to slower-than-anticipated EU project approvals. The structural primary supplus, an indicator of fiscal effort, weakened further in 2002 and, at $31 / 2$ percent of GDP, was almost 2 percentage points below its 1999 level. With interest payments declining substantially during 1999-2002, the structural deficit (net of asset sales) remained unchanged during this period of strong growth and, at 2 percent of GDP, was well above the euro-area average. 


\section{Box 2. Fiscal Accounting Revisions}

In cotsultation with Eurostat, national accounts-based general government data for recent years have been revised significantly. The revisions focused on two aspects. First, some categories of expenditures (e.g., recurring capital injections to public enterprises and debt assumptions) were included above the line, affecting the fiscal deficit; these were previously classified as financial transactions "below the line." Second, debt stocks were revised up to include debt issued by special purpose vehicles as well as share-exchangeable bonds and privatization certificates used for similar purposes.

As a result, the general government balance weakened significantly; for example, for 2001 a small ( 0.1 percent of GDP) sumplus was transformed into a 1.4 percent deficil. The consolidated general government debt ratio has been revised upward by about 8 percentage points of GDP.

Greece: Revisions in General Government Accounts

(In percent of GDP)

\begin{tabular}{|c|c|c|c|c|}
\hline & \multicolumn{2}{|c|}{2001} & \multicolumn{2}{|c|}{2002} \\
\hline & Orig. Est. & Revised & Org. Proj It & Est. 1 \\
\hline Total eurrent resouttes & 43.7 & 41.9 & 43.5 & 41,4 \\
\hline Total curretin expenditure & 403 & 39.2 & 39.1 & 38.7 \\
\hline Net capingl expendüure & 3.4 & 4.2 & 3.5 & 4.0 \\
\hline Ovesall balance & 0.1 & -1.4 & 0.8 & -1.2 \\
\hline Pritomy yophes & 6.6 & 4.8 & 6.4 & +3 \\
\hline $\begin{array}{l}\text { Memorendum item: } \\
\text { Connolidatiod }\end{array}$ & 09.6 & 1000 & 973 & 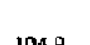 \\
\hline
\end{tabular}

Source: Ministry of Eeonouny and Firance.

1/ Authorities' projection and tetimate,

18. For 2003, the discussions focused on the adequacy of the fiscal targets and on potentlal risks, with the staff expressing concerns on both fronts:

- The 2003 budgef targeted a small reduction in the fiscal deficit, amid sizable revenue relief from a tax reform. The budgeted decline in the fiscal deficit to 0.9 percent of GDP was fully attributable to the envisaged $1 / 4$ percentage point reduction in interest expenditures (Table 5). The authorities noted that the recent tax reform (discussed below) would result in revenue losses of about 0.6 percent of GDP in 2003 , only partly offset by further revenues from settling tax arrears of the self-employed. 
General Goverament Accounts, 2001-03

(In percent of GDP)

\begin{tabular}{|c|c|c|c|c|c|}
\hline & \multirow[t]{2}{*}{2001} & \multicolumn{2}{|c|}{2002} & \multicolumn{2}{|c|}{2003} \\
\hline & & Eudiget 17 & $\overline{\text { Est. }}$ & Burget $\bar{U}$ & Staff \\
\hline Overali balance & -1.4 & 0.8 & -1.2 & 0.9 & $-1,4$ \\
\hline Revenue & 44.4 & 47.1 & 43,5 & 43.2 & 43,3 \\
\hline Expendinure & 45.8 & 46.3 & 45.1 & 44.1 & 44.7 \\
\hline of which: interest & 0.3 & 5.6 & 5.5 & 5.2 & 5.3 \\
\hline \multicolumn{6}{|l|}{ Menorapdum itetns: } \\
\hline Structural overall balance $3 /$ & -2.5 & -3.1 & -2.1 & -2.0 & -2.2 \\
\hline Structural primary balance $y$ & 3.8 & 3.2 & 3.5 & 3.4 & 3.1 \\
\hline General government debt & 107.0 & 97.3 & 1049 & 99.1 & 100.1 \\
\hline
\end{tabular}

Sources: Miriasty of Fconomy and Finance; and Fund staff projections.

If Ministry of Exonomy and Finance projection, which, given subsequent gecers govetutuest aceounts revisions, is atot fully comparable with fogimales for 2002 and with dafn for acher years.

$2 /$ Ministry of Economy and Finatice, March 2003 projection.

3/ Stractural balances are based on tho staffe extimates of potential output and, for 2001, exclude UMTS revenues equivalent to 0.4 percent of CDP.

- The government stressed the growth-orientation of the budget, while staff saw a case for accelerating fiscal consolidation. There was agreement that fiscal policy needed to take into account the strength of economic activity, relatively accommodative monetary conditions, emerging macroeconomic imbalances, and Greece's very high public debt. In staff's view, all these considerations argued for substantive fiscal consolidation, reducing the structural deficit by about $3 / 4$ percent of GDP per annum in 2003 and in subsequent years (see below). However, under the budget's GDP growth assumption (3.8 percent of GDP), the structural deficit would remain broadly unchanged-while ECOFIN, in its January 2003 review of the Stability Program, had called for structural adjustments of at least $1 / 2$ percent of GDP per annum. The authorities ruled out a more ambitious target by noting expenditure needs (for example, related to the Olympics and for education) and risks to growth in 2003 within an unsettied external environment. Staff thought that growth risks should be addressed by letting the automatic stabilizers play around sufficiently ambitious structural deficit targets. The authorities stressed, however, the political importance of achieving headline deficit targets and expressed reservations about letting automatic fiscal stabilizers play fully.

- The authorities were confident that risks of expenditure slippages, which staff saw as sizable, would be contained. The budget targets a decline in primary current expenditures of 0.7 percent of GDP, to be achieved with better control of wage expenditures and with declines in real (and sometimes nominal) expenditures for several other categories. Aside from uncertainties surrounding the cost of the tax reform, staff noted that sufficient measures were not in place to achieve the targeted expenditure savings-while the authorities expected that the expenditure targets could be secured, but intended to introduce additional measures, if needed. More recent data for the central government indicate larger-thanexpected deficits in the early part of 2003. 
19. Concerning the medium term, the updated Stability Program envisioned a substantial decline in the public debt ratio, albeit to levels that exceeded previous targets. Earlier Programs had targeted reducing the public debt to 60 percent of GDP by 2010 , and staff thought that this remained a broadly appropriate strategy: it would address risks entailed by the present high debt (Appendix III) and take advantage of a "window of opportunity" prior to the onset of aging-related expenditure pressures. The target would require an average annual budget surplus of about $1 / 2$ percent of GDP during 2003-10-a level recorded in many industrial countries in the past. This could be achieved by strengthening the structural balance by about $3 / 4$ percent per annum over the Stability

Meeting the 60 percent of GDP Public Debt Target in 2010

(In percent of GDP; period average, except where atherwise indicared)

\begin{tabular}{|c|c|c|c|}
\hline & 2002 & $2003-06$ & $2007-10$ \\
\hline \multicolumn{4}{|l|}{ Scenarlo I (Staff) } \\
\hline Public debt (end-af-period) & 104.9 & 79.9 & 60.0 \\
\hline Below-the-lite activities (net) $1 /$ & 4.4 & 0.0 & 0.0 \\
\hline Ptimary surplus needed to thet the 2010 debt target & 4.3 & 5.3 & 5.0 \\
\hline Overall balance needed to raeat the 2010 debt target & -1.2 & 0.5 & 1.1 \\
\hline \multicolumn{4}{|l|}{ Scenario II (Stability Progrand) $2 /$} \\
\hline Public dobt (end-of-period) & 105.3 & 87.9 & 60.0 \\
\hline Below-the-line activities (net) 3/ & 4.4 & $\mathbf{2 . 0}$ & 2.3 \\
\hline Primary surplus needed to meet the 2010 debt target $2 /$ & 4.4 & 4.8 & 9.2 \\
\hline Overall bal ance neoded to moet the 2010 debt target 2 & -2.1 & .0 .1 & 5.] \\
\hline
\end{tabular}

\footnotetext{
Sources: The 2002 Update of the Hellenic Stability and Growth Program: 2002-06; and Fund staff calculations (seo tert for details).

I/ Actual diats for 2002, assumed zero thereafter.

2/ Stability Program for 2002-06; for 2007-10, stable primary surphus needed to meet 60 percent of GDP debt targer in 7010. 3/ Activities as implied by the Stabtitiny Frogrem for 2002-06, equal to the 2006 ghare of GDP thereafter.
}

Program horizon through 2006, and strictly limiting debt-creating below-the-line transactions (see below; and Scenario I in the text table). The staff noted that with limited progress in the early years, the updated Program implied very high (and probably unrealistic) primary surpluses in the second half of the decade, if debt were to be reduced to 60 percent of GDP by 2010 (see Scenario II). However, the authorities thought that reaching the 60 percent debt ratio by 2010 would unduly slow economic growth.

\section{Expenditure restraint and pension reform}

\section{There was broad agreement that successful fiscal consolidation required} spending restraint. In a clear break from previous outcomes (see Figure 7), the government envisaged a decline in primary current spending by $1 \frac{1}{2}$ percentage points of GDP during 2003-07. The discussions covered key prerequisites:

- Expenditure restraint in major categories: On public sector wages and employment, the authorities saw room to restrain future wage increases, after wages had risen at more than twice the rate of inflation in 2002. They also focused on steps to strengthen efficiency, including through the introduction of part-time employment, but envisaged no substantive reductions in civil service employment -an area where staff saw room for 
savings, taking advantage of attrition and redeployment to areas of greatest need. Hiring plans announced in the spring pointed to employment increases that could exceed attrition rates by a wide margin, rendering ineffective, once again, the limit of one new hire per five job leavers (which was extended through end 2003, but exempted large areas of government employment). On health care, reforms underway included increased decentralization and improved service quality; the authorities were hopeful that the devolution of financial responsibility and strengthened auditing procedures could help control spending. The authorities also saw room for curtailing Greece's relatively high defense expenditure, in view of easing tensions with neighboring countries and in the Balkans. They would review staff's suggestion for reducing capital transfers (over $2 \frac{1}{2}$ percent of GDP in 2002) and subsidies, taking full advantage of privatization and cost recovery opportunities in remaining public enterprises.

- Measures to strengthen budget planning, monitoring, and control: To safeguard the fiscal targets, the government intended to strengthen budget planning and control. A new "Code of Fiscal Stability" was presented to parliament that would limit borrowing, for all levels of the general govemment and public sector entities, to infrastructure and military equipment expenditures. The authorities also planned to introduce multiyear budgeting in 2004; in this context, they noted with interest staff's suggestion for establishing binding, multiyear expenditure ceilings for all levels of the general government.

\section{Rapid public debt reduction would require further steps to rein in sizable below-} the-line transactions. These transactions, including debt assumptions and equity injections by the state, do not affect the Maastricht-based deficit but raise public debt (see last year's Country Report). Notwithstanding recent Eurostat revisions, which reclassified some of these transactions as capital transfers, below-the-line net outlays amounted to $4 \frac{1}{2}$ percent of GDP in 2002; and net outlays of 2 percent of GDP per annum during 2003-06 remained in the Stability Program. The authorities thought that it would be difficult to limit gross transactions to be fully offset by privatization receipts, as staff suggested. They were open, however, to institute more timely and extensive publication of related information to allow a comprehensive evaluation of all transactions.

\section{A pension reform adopted in $\mathbf{2 0 0 2}$ was expected to improve several aspects of} Greece's pension system, but largely failed to address longer-term spending pressures (Box 3). The government emphasized that the reform had established common parameters for all pensioners and introduced measures to consolidate the highly fragmented system of funds. The staff regretted that the reform would result in few savings, with official projections pointing to an almost doubling (in relation to GDP) of already relatively high pension expenditures over the coming decades, by far the largest increase projected for any EU country. The government noted that considerable time remained until expenditures would start to rise rapidly, and ruled out further reforms at this time-except possibly for steps to integrate additional funds into the main system and to fight contribution evasion. 


\section{Box 3. Pension Reform in Greece}

The Greek pension system faces exceptionally strong spending pressures. As discussed in a background paper to last year's consultation, pension expenditures are projected to increase, absent reforms, by more than in any other EU country, almost doubling in relation to GDP (from already relatively high levels) by 2050 .

A pension reform was adopted in mid-2002. The reform provides additional funding for the main pension fund (KKA) - with state transfers of 1 percent of GDP annualiy, on top of other state contributions. The bill encourages primary funds to merge with IKA, permits private, fully funded pension funds, extends the period used to calculate IKA pension benefits to cover the last five working years, and introduces some disincentives for early retirement. However, major savings from an earlier (1992) reform were lost by establishing a unique replacement ratio of 70 percent for all employees, both those who entered the labor force before and after 1992-a decline from 80 percent for the first group but an increase from 60 percent for the second. A newly established independent authority will supervise and monitor social

Greece: Public Pensien Expenditurex, 2000-50 (In percent of GDP

\begin{tabular}{lllllll}
\hline & 2000 & 2014 & 2020 & 2090 & 2040 & 2050 \\
\hline & & & & & & \\
Prereform estimates & 12.5 & 11.8 & 13.5 & 17.6 & 22.5 & 24.0 \\
Poatreform estimates 1/ & 12.6 & 12.2 & 13.8 & 17.3 & 21.4 & 22.6 \\
EU & 10.4 & 10.4 & 11.5 & 13.0 & 13.6 & 13.3
\end{tabular}

Sources: Ministry of Labor and Sotial Security; and EU, Economic Policy Cetmitues (2001).

1/ Data for 2000 include increases in some pensions not relatad to the reform. security developments.

Despite some positive elements, the $\mathbf{2 0 0 2}$ reform largely failed to address underlying expenditure pressures. Based on official projections (see text table), postreform spending will be marginally higher over the coming two decades. Notwithstanding small savings thereafter, spending would still rise well above levels currently projected for other EU countries.

\section{Public sector transparency and tax reform}

\section{There was a broad consensus on the need to increase transparency and} accountability in the public sector (see also Supplement 1, the updated self-assessment against the IMF Code of Good Practices on Fiscal Transparency). The authorities pointed to pending progress: the previously mentioned "Code of Fiscal Stability" was expected to improve monitoring and accountability; and a new accounting and auditing system was to be introduced for the central government. Amid an extensive public debate, efforts were also under consideration to strengthen governance more generally, including by further limiting civil servants' discretion and room for abuse (see also Section III.D below).

\section{The recent tax reform was an important step toward increasing transparency} and establishing a simpler and more equitable system (Box 4). The government highlighted the reform's focus on modernizing and simplifying the tax system, reducing administrative costs, improving equity and combating tax evasion, and lowering the tax burden on labor income. The staff agreed that the reform was an important step toward a more transparent system, with further efforts needed to reduce sizable distortions in corporate 
and other taxation (discussed in a forthcoming background paper). The authorities concurred that reductions in the tax burden should only proceed if sufficient expenditure savings had been secured.

\section{Box 4. Tax Reform}

Following a fundamental review of the tax system, a tax reform took effect at the beginning of 2003, aimed at improving the system's neutrality and simplicity, while reducing the tar barden on labor income. The reform simplified bookkeeping regulations for the self employed and for VAT; reduced the number of personal income tax brackets and increased the zero-rate bracket; abolished a large number of exemptions and deductions and replaced others with limited tax credits; eliminated most presumptive taxation and stamp duties; and reduced property transfer, inheritance, and gift taxes. The cost of the tax reform was officially estimated at $€ 900$ million ( 0.6 percent of GDP) for 2003, and an additional $€ 540$ million for 2004.

The reforms adopted should help to simplify the tax system, and improve horizontal and vertical equity, but a number of further tax issues remain to be addressed. Among others, the corporate income tax rate is relatively high compared with other EU countries, but extensive deductions and allowances result in widely varying effective rates, with implications for allocative efficiency and transparency. The creation of a modern system of property taxation awaits the establishment of a national land registry.

\section{Labor and Product Markets}

\section{Greece's labor market performance in recent years has been disappointing,} notwithstanding some improvements in 2002. Despite strong economic growth, no appreciable progress has been made toward the main Lisbon targets-one of the priority areas for Greece's EU presidency during the first half of 2003. In particular, employment has stagnated since 1998, and participation rates, the second lowest in the EU, have declined further. The latter has led to a fall in the unemployment rate, which remains, however, among the highest in the EU. Labor union representatives attributed the limited aggregate employment gains to the extensive use of overtime work and declining employment in agriculture, not compensated for by increased employment in other sectors. Employers" representatives pointed to a lack of flexibility in the labor market, an area where Greece scores relatively poorly in international comparisons. The staff reiterated the need for steps to facilitate labor market entry by women and the young, including steps to improve job matching and to allow for sufficient wage differentiation. While the latter found little sympathy, the authorities and labor union representatives were hopeful that labor market matching problems would ease with recent education reforms and measures to strengthen active labor market policies-and a pending review of the latter would provide the basis for future reforms.

26. The authorities emphasized that further product market reforms conld strengthen medium-term growth. Notwithstanding recent steps-including privatizations, amid difficult market conditions-Greek product market liberalization continues to score 
poorly vis-à-vis other $\mathrm{OECD}$ countries. The Competition Authority has been unsuccessful in recruiting a sufficient number of staff, severely limiting its effectiveness; the authorities concurred that progress in this area and other steps to strengthen competition could have the added benefit of improving price competitiveness. In the electricity sector, the regulator's powers in some areas (for example, for setting tariffs) lag behind those envisaged in relevant EU directives, and efficiency gains have been hampered by continued cross-holdings and high entry barriers.

27. Notwithstanding some progress in recent years, excessive administrative burdens and a lack of transparency continue to impede the formation of new enterprises and foreign direct investment. The authorities were optimistic that an ongoing effort to reduce and simplify the number of licenses and the creation of both citizen service and investment centers would address some of these problems. They also stressed progress in improving transparency in the corporate sector: the adoption of international accounting standards, applying to all listed companies in 2003 (two years abead of EU requirements); a new corporate governance law; and a proposed bill, strengthening auditing procedures. However, there was a widespread consensus that extensive discretionary powers in the civil service, including in tax administration, opened avenues for abuse, and that administrative hurdles, while reduced, continued to interfere with activities in many areas. The authorities concurred that reforms in these areas could also facilitate FDI inflows into Greece.

\section{E. Other Issues}

28. Greece subscribed to the SDDS in November 2002. This was accompanied by statistical improvements in many areas (Appendix In). However, a recent data ROSC mission highlighted important remaining weaknesses, including reporting delays for high-frequency economic indicators, the large differences between settlements and national accounts-based external sector data, and shortcomings in the fiscal area.

29. The authorities reiterated their commitment to anti-money laundering efforts and steps against the financing of terrorism. Greece complies with all of the Financial Action Task Force's recommendations for anti-money laundering measures, and has adopted the OECD's anti-bribery convention.

30. The government supported further external trade liberalization, particularly for exports from developing countries. Greece, as a net importer of their products, was seen as benefiting from falling prices following trade liberalization. With a relatively large agricultural sector, agricultural trade liberalization could significantly affect the domestic economy. The authorities noted, however, that present EU proposals would generally not affect small farmers, which formed the majority in Greece.

\section{StAFF APPRAISAL}

31. The Greek economy continues to enjoy the fruits of earlier successful policy adjustments and of its entry into monetary union. The stable macroeconomic policy environment and low interest rates provided by euro-area participation as well as earlier 
reforms have underpinned an extended period of strong economic growth. This is even more notable against the background of weak activity in many partner countries. Moreover, for the first time in several years, employment increased in 2002 and the unemployment rate has fallen below 10 percent.

32. The policy challenge now is to address emerging macroeconomic imbalances and lay the foundation for continued rapid convergence in living standards. High levels of public debt, a large external current account deficit, rapidly rising private sector indebtedness, and pervasive structural impediments to growth all point to a need for prudent macroeconomic policies, supervisory vigilance, and structural reforms. Strong growth and upcoming elections could weaken the resolve for policy action at this juncture, but delaying such action risks accumulating an adjustment burden that would ultimately require considerably more difficult steps.

33. Maintaining strong medium-term growth while engendering a gradual narrowing of the external current account deficit will require strengthening external competitiveness. Persistent large current account deficits over the medium term would add to already relatively high external debt levels and weigh on future growth prospects. The onus to address these risks by strengthening competitiveness falls principally on wage restraint, which has not yet sufficiently reflected the constraints imposed by monetary union. Future public sector and minimum wage agreements will have to lead by example. Price competitiveness and productivity would also benefit from reforms to strengthen competition.

34. In the financial sector, rapid credit growth highlights evolving risks that require added supervisory vigilance. The recently liberalized banking sector remains untested in an economic downtum, and supervisors have already responded to developments by strengthening provisioning requirements. Additional steps may be warranted if credit continues to grow rapidly-including steps to prevent a further weakening of bank capital ratios. The recent upgrading of supervisory expertise was well placed, and needs in this area should be assessed on an ongoing basis. In the insurance sector, a strengthening of supervision is urgently required-including the establishment of a fully independent and effective supervisory agency, which would need to coordinate closely with other supervisors. It would be useful to review broader financial sector issues in the context of an FSAP.

\section{Fiscal policy has to play its role in safeguarding macroeconomic stability and} securing a rapid decline in the public debt ratio--exigencies not adequately addressed by the 2003 budget. Developments early in the year indicate that the 2003 expenditure targets are unlikely to be met, and the time has come to follow up on the authorities' intention to redress any slippages. More broadly, the current economic buoyancy provides a propitious setting for advancing structural fiscal consolidation-while the government's target, under the budget's growth assumptions, implies no improvement of the structural deficit in 2003. The adjustment steps should set consolidation on a steady path toward reducing the public debt ratio to 60 percent of GDP by 2010 , as envisaged in earlier Stability Programs. Around this path, automatic fiscal stabilizers have a useful role to play. 
36. Expenditure restraint will be pivotal for durable fiscal consolidation. Following strong increases in recent years, public sector wage restraint is needed-but there also remains a case for more determined steps to reduce public sector employment. On health care, measures to strengthen auditing and expenditure control should help address the challenges provided by an increasingly decentralized system. Opportunities to reduce Greece's high military expenditures should also be seized. Moreover, rapid debt reduction will require limiting debt-creating below-the-line transactions to, at most, future privatization receipts; and there remains a need to publicly disclose all relevant details about these transactions.

\section{The 2002 pension reform is expected to strengthen some aspects of the pension} system, but long-run spending pressures remain largely unaddressed. The reform should facilitate consolidation of public pension funds and the establishment of private funds. However, pension outlays are still set to increase considerably more (in relation to GDP) than in any other EU country. This casts doubts on overall fiscal sustainability that need to be addressed well ahead of the most adverse impact from population aging.

\section{Several initiatlves hold out the prospect of raising public sector transparency} and efficiency, areas where significant scope remains for further improvements. The ptanned "Code of Fiscal Stability" could enhance monitoring and accountability of all public sector entities, but strict enforcement and tight borrowing limits will be essential for its effectiveness. Instituting binding, multiyear expenditure ceilings would also raise transparency and facilitate efficient expenditure planning and control. There is also a case for further limiting discretion and the room for abuse in the civil service.

39. The recent tax reform should lead to important simplifications of the tax system and increased equity of the tax burden. The elimination of various stamp duties and tax exemptions and deductions will simplify tax administration. The reform also provides sizable tax relief, in particular for households. Future steps need to reduce distortions in corporate and other taxation-with tax relief proceeding only if sufficient expenditure savings have been secured. Tax amnesties could undermine welcome efforts to strengthen tax administration and should be avoided.

40. Greece's labor market performance has been disappointing, notwithstanding some recent gains, and progress toward the Lisbon targets will require further decisive action. Particularly needed are steps to facilitate labor market entry by women and the young. The pending review of active labor market policies could provide lessons for facilitating labor market matching - an area where recent education reforms also hold out promise.

41. Per capita income in Greece remains well below the EU average and continued, rapid catch-up will depend on further structural reforms. Privatization progressed in 2002, amid difficult market conditions. However, the Competition Authority still has to assume a more active role in safeguarding competition, which could also strengthen price 
competitiveness. In the electricity sector, easing entry barriers and divestitures by the dominant firm may be necessary for effective competition and expansion of power generation, and consideration should be given to further strengthen the powers of the regulator.

42. Greece became a subseriber to the IMF's Special Data Dissemination Standard and implemented considerable statistical improvements-although further steps are needed in this regard. Recent initiatives improved the quality and timeliness of statistical data in many areas (Appendix II). Nevertheless, timeiy assessments of economic developments would benefit from additional progress, including on fiscal statistics.

43. The authorities' support for the full liberalization of imports from the least developed countries is welcome and Greece is encouraged to raise official development assistance (ODA). While ODA was increased considerably in recent years, it remains (at about 0.2 percent of GNI) low compared with most advanced economies and well below the UN target.

44. It is recommended that the next Article IV consultation with Greece be held on the standard 12-month cycle. 
Table 1. Greece: Selected Economic Indicators, 1997-2003

(Percentage changes, unless otherwise indicated)

\begin{tabular}{|c|c|c|c|c|c|c|c|}
\hline & 1997 & 1998 & 1999 & 2000 & 2001 & $\frac{2002}{\text { Est. }}$ & $\frac{2003}{\text { Proj. }}$ \\
\hline \multicolumn{8}{|l|}{ Domestic econamy } \\
\hline GDP & 3.6 & 3.4 & 3.6 & 4.2 & 4.1 & 4.0 & 3.6 \\
\hline Output gap & -0.3 & 0.1 & 0.5 & 1.2 & 1.6 & 1.9 & 2.0 \\
\hline Domestic demand & 3.5 & 4.6 & 2.8 & 3.9 & 3.1 & 3.9 & 3.9 \\
\hline Private consumption & 2.7 & 3.5 & 2.9 & 2.6 & 2.9 & 2.5 & 3.0 \\
\hline Public consumption & 3.0 & 1.7 & 1.6 & 2.0 & -0.9 & 6.2 & 1.5 \\
\hline Gross fixed espital formation & 6.8 & 10.6 & 6.2 & 8.0 & 5.9 & 6.7 & 8.4 \\
\hline Private & 5.8 & 11.0 & 7.2 & 5.7 & 6.9 & 7.8 & 8.7 \\
\hline Pablic & 12.3 & 8.3 & 1.5 & 20.1 & 1.1 & 1.7 & 7.0 \\
\hline Change in stocks (contriburtion) & 0.0 & 0.0 & -0.6 & 0.2 & 0.1 & 0.0 & 0.0 \\
\hline Foreign balance (contribution) & -0.1 & -1.6 & 0.5 & -0.1 & 0.7 & -0.2 & -0.6 \\
\hline Exports & 20.0 & 53 & 8.0 & 19.7 & -1.6 & -4.5 & 3.7 \\
\hline Imports & 14.2 & 92 & 3.8 & 14.5 & -3.4 & -2.7 & 4.9 \\
\hline Unemployment rate & 10,3 & 11.1 & 11.9 & 11.1 & 10.4 & 9.9 & 9.8 \\
\hline Employment 1f & -0.6 & 4.1 & -0.5 & 0.0 & -0.8 & 1.0 & 0.6 \\
\hline Average compensation of employees (economy wide) & 13.8 & 5.4 & $5+0$ & 6,1 & 5.3 & 6.2 & 5.8 \\
\hline Unit labor casts (economy wide) & 9.2 & 6.1 & 1.3 & 1.7 & 0.8 & 2.5 & 2.7 \\
\hline Consumer prices, end of period & 4.7 & 3.9 & 2.7 & 3.9 & 3.0 & 3.4 & 3.5 \\
\hline Consumer prices, period average & 5.5 & 4.8 & 2.6 & 3.2 & 3.4 & 3.6 & 3.8 \\
\hline Consumer prices (HICP), period average & 5.4 & 4.5 & 2.1 & 2.9 & 3.7 & 3.9 & 3.8 \\
\hline GDP deflator & 6.8 & 5.2 & 3.0 & 3.4 & 3.4 & 3.7 & 3.6 \\
\hline External sector & & & & & & $=$ & \\
\hline Trade balance (in percent of GDP, settlements basis) & -14.2 & -13.6 & -14.3 & -17.8 & -16.3 & -16.1 & -16.9 \\
\hline \multicolumn{8}{|l|}{ Current account (including capital transfers; } \\
\hline in percent of GDP, settlements basis) & -4.0 & -3.0 & -4.0 & -6.8 & -6.2 & -6.1 & -6.9 \\
\hline Nominal effective exchange rate & -1.5 & -4.6 & -0.7 & -5.8 & 0.7 & 0.7 & ... \\
\hline Real effective exchange rate (consumer prices) & 0.8 & -2.7 & 0.1 & -6.1 & 1.0 & 2.9 & $\ldots$ \\
\hline Real effective exchange rate (manufacturing ULCs) & 3.7 & -3.3 & 0.8 & -3.1 & 0.5 & 3.1 & ... \\
\hline \multicolumn{8}{|l|}{ Public finances (gevera] government, in percent of GDP) } \\
\hline Carreat retrenues & 38.8 & 40,3 & 41.5 & 43.2 & 41.9 & 41.4 & 40.9 \\
\hline Current expenditures & 40.2 & 40.2 & 39.8 & 40.5 & 39.2 & 38.7 & 38.3 \\
\hline Primary expenditures & 32.0 & 32,4 & 32.6 & 33,5 & 32.9 & 33.2 & 33.0 \\
\hline Interest expenditures & 8.2 & 7.8 & 7.2 & 7.0 & 6.3 & 5.5 & 5.3 \\
\hline Net capital spending & 2.6 & 2.5 & 3.5 & 4.5 & 4.2 & 4.0 & 4.0 \\
\hline Overall balance & -4.0 & -2.5 & -1.8 & -1.9 & -1.4 & -1.2 & -1.4 \\
\hline Primary balance & 4.2 & 5.3 & 5.4 & 5.1 & 4.9 & 4.3 & 3.9 \\
\hline Structural primary balance $2 /$ & 4.3 & 5.3 & 5.2 & 4.6 & 3.8 & 3.5 & 3.1 \\
\hline Structural overall balance $2 /$ & -3.9 & -2.5 & -2.0 & -2.5 & -2.5 & -2.1 & -2.2 \\
\hline Debt & 108.2 & 105.8 & 105.1 & 106.2 & 107.0 & 104.9 & 100.1 \\
\hline \multicolumn{8}{|l|}{ Financial variables } \\
\hline Greek contribution to eura area $\mathrm{M3} 3 /$ & 7.8 & 9.8 & 5.6 & 17.1 & 7.4 & -1.8 & s. \\
\hline Credit to enterprises and households & 11.0 & 9.7 & 12.2 & 27.6 & 24.8 & 16.9 & $\ldots$ \\
\hline 3-month treasury bill rate (average) & 10.1 & 11.9 & 9.8 & 7.2 & 3.8 & 2.9 & $\ldots$ \\
\hline 12-month treasury bill rate (average) & 10.4 & 11.6 & 8.9 & 6.2 & 4.1 & 3.2 & $\ldots$ \\
\hline Short-term bank lending rate (average) & 18.9 & 18.6 & 15.0 & 12.3 & 8.6 & 7.4 & $\cdots$ \\
\hline
\end{tabular}

Sources: National Statistical Service; Ministry of National Economy; Bank of Greece; and Fund staff estimates and projections.

1/ Data for 1998 affected by registration of previously illegal foreign warkers.

2/ For 2001, exchedes UMTS revenues equivalent to 0.4 percent of GDP.

3/ Data prior to 2000 refer to growth of Greek liquidity measure M4N. 
Table 2. Greece: Balance of Payments, 1997-2002

(In millions of euro)

\begin{tabular}{|c|c|c|c|c|c|c|}
\hline & $199 ?$ & 1998 & 1999 & 2000 & 2001 & $\frac{2002}{\text { Est. }}$ \\
\hline $\begin{array}{l}\text { Current account } 1 / \\
\text { (In percent of GDP) }\end{array}$ & $\begin{array}{r}-4,266 \\
-4.0\end{array}$ & $\begin{array}{r}-3,286 \\
-3.0\end{array}$ & $\begin{array}{r}-4,800 \\
-4.3\end{array}$ & $\begin{array}{r}-8,372 \\
-6.9\end{array}$ & $\begin{array}{r}-8,169 \\
-6.2\end{array}$ & $\begin{array}{r}.8,635 \\
-6.1\end{array}$ \\
\hline $\begin{array}{l}\text { Trade balance } \\
\text { Exports } \\
\text { lmports }\end{array}$ & $\begin{array}{r}-15,235 \\
5,690 \\
20,925\end{array}$ & $\begin{array}{r}-14,823 \\
5,923 \\
20,746\end{array}$ & $\begin{array}{r}-16,889 \\
8,030 \\
24,919\end{array}$ & $\begin{array}{r}-21,927 \\
11,099 \\
33,026\end{array}$ & $\begin{array}{r}-21,611 \\
11,545 \\
33,156\end{array}$ & $\begin{array}{r}-22,709 \\
10,434 \\
33,142\end{array}$ \\
\hline Services & 5,739 & 6,073 & 6,847 & 8,711 & 9,150 & 10,755 \\
\hline Receipts & 8,989 & 9,968 & 15,576 & 20,977 & 22,076 & 21,131 \\
\hline Travel & 4,593 & 5,514 & 8,296 & 10,061 & 10,580 & 10,285 \\
\hline Transportation & 1,659 & 1,932 & 4,872 & 8,641 & 9,113 & 8,523 \\
\hline Other services & 2,737 & 2,523 & 2,408 & 2,275 & 2,383 & 2,323 \\
\hline Payments & 3,250 & 3,896 & 8,729 & 12,266 & 12,926 & $.10,376$ \\
\hline Travel & 1,177 & 1,558 & 3,761 & 4,949 & 4,651 & 2,549 \\
\hline Transportation & 326 & 429 & 2,266 & 4,458 & 5,351 & 5,030 \\
\hline Other services & 1,747 & 1,909 & 2,703 & 2,859 & 2,924 & 2,798 \\
\hline Income & $-1,391$ & $-1,381$ & -627 & -955 & $-1,981$ & $-2,073$ \\
\hline Receipts & 1,110 & 1,362 & 2,414 & 3,039 & 2,100 & 1,626 \\
\hline Compensation of employees & 249 & 335 & 577 & 631 & 606 & 510 \\
\hline Investment income & 861 & 1,027 & 1,838 & 2,408 & 1,494 & 1,117 \\
\hline Payments & 2,501 & 2,743 & 3,041 & 3,994 & 4,082 & 3,700 \\
\hline Compensation of employees & 300 & 323 & 231 & $=272$ & 281 & 240 \\
\hline Investment income & 2,200 & 2,420 & 2,809 & 3,722 & 3,801 & 3,459 \\
\hline Transfers & 6,621 & 6,846 & 5,868 & 5,799 & 6,273 & 5,391 \\
\hline Receipts & 6,656 & 7,276 & 6,795 & 8,127 & 8,946 & 7,801 \\
\hline Official & 4,058 & 4,327 & 4,250 & 5,332 & 5,922 & 5,486 \\
\hline Other sectors & 2,598 & 2,949 & 2,545 & 2,795 & 3,024 & 2,315 \\
\hline Payments & 35 & 430 & 927 & 2,328 & 2,673 & 2,410 \\
\hline Official & 11 & 11 & 190 & 1,569 & 1,867 & 1,696 \\
\hline Other sectors & 24 & 420 & 737 & 759 & 806 & 714 \\
\hline Fingmcial account & 5,673 & 3,395 & 4,748 & 8,906 & 6,935 & 10,310 \\
\hline Direct investment & 1,463 & 309 & 9 & $-1,116$ & 1,088 & -643 \\
\hline Portfolio investment & 1,434 & 10,700 & 5,706 & 9,108 & $9,4652 /$ & $10,9382 /$ \\
\hline Other investment & $-2,547$ & $-3,220$ & -518 & $-4,857$ & $-9,7952 \%$ & $1,9992 /$ \\
\hline Reserve assets & 5,323 & $-4,395$ & -449 & 5,772 & $6,1772 /$ & $-1,9832 /$ \\
\hline Errors and omissions & $-1,407$ & -109 & 52 & -534 & 1,234 & $* 1,675$ \\
\hline
\end{tabular}

Sources: Bank of Greece; $\mathrm{MF}, I F S$, and Fund staff projections.

1/ Includes capital transfers.

2/ Affected in offsetting amounts by the release of commercial bank foreign exchange redeposits with the Bank of Greece resulting from the harmonization of reserve requirements upon entry into the euro area. 
Table 3. Greece: Stability and Growth Program and Staff's Medium-Term Scenario, 2002-08 1/ (In percent of GDP, unless otherwise indicated)

\begin{tabular}{lrrrrrrr}
\hline & 2002 & 2003 & 2004 & 2005 & 2006 & 2007 & 2008 \\
\hline Stability and Growth Program & & & & & & & \\
GDP (percent change) & & & & & & & \\
Private consumption deflator (percent change) & 3.8 & 3.8 & 4.0 & 3.7 & 3.6 & $\ldots$ & $\ldots$ \\
Gross domestic investment & 3.1 & 2.7 & 2.8 & 2.6 & 2.6 & $\ldots$ & $\ldots$ \\
General govennment balance & 23.4 & 24.6 & 25.2 & 25.6 & 25.9 & $\ldots$ & $\ldots$ \\
General government primary balance & -1.1 & -0.9 & -0.4 & 0.2 & 0.6 & $\ldots$ & $\ldots$ \\
General government debt & 4.4 & 4.4 & 4.6 & 5.0 & 5.2 & $\ldots$ & $\ldots$ \\
& 105.3 & 100.2 & 96.1 & 92.1 & 87.9 & $\ldots$ & $\ldots$ \\
Staff proJectlons (unchanged policy scenario) & & & & & & & \\
GDP (percent change) & & & & & & & \\
Output gap (percent of potential output) & 4.0 & 3.6 & 3.6 & 2.5 & 2.4 & 2.4 & 2.5 \\
Consumer prices (HICP, period average, percent change) & 1.9 & 2.0 & 2.2 & 1.6 & 1.0 & 0.5 & 0.0 \\
Gross domestic investment & 3.9 & 3.8 & 3.0 & 2.8 & 2.8 & 2.8 & 2.8 \\
Current account balance (settlements basis) $2 t$ & 23.2 & 24.0 & 24.6 & 24.4 & 24.1 & 23.8 & 23.5 \\
Goods balance & -6.1 & -6.9 & -6.6 & -6.4 & -5.9 & -5.5 & -4.9 \\
Service balance & -16.1 & -16.9 & -16.7 & -16.4 & -16.2 & -16.1 & -15.8 \\
Other & 7.6 & 8.1 & 8.2 & 8.2 & 8.6 & 8.9 & 9.3 \\
General government balance & 2.4 & 1.9 & 1.9 & 1.8 & 1.7 & 1.6 & 1.5 \\
General government primary balance & -1.2 & -1.4 & -1.1 & -0.7 & -0.8 & -1.2 & -1.5 \\
General government debt 3/ & 4.3 & 3.9 & 3.9 & 4.1 & 3.9 & 3.6 & 3.4 \\
& 104.9 & 100.1 & 97.5 & 96.0 & 94.5 & 93.6 & 92.9 \\
\hline
\end{tabular}

Sources: Ministry of Economy and Finance, "The 2002 Update of the Hellenic Stability and Growth Programme: 2002-06" (December 2002); and Fund staff estimates and projections.

V/ Authorities' figures are based on December 2002 Stability Program, and therefore may differ from fiscal data contained in Table 1. Differences from staff projections are partly related to different assumptions on potential growth (see text).

$2 /$ Includes capital account.

3/ The staff assumes that the amount of below-the-line capital injections and other spending, net of privatization and other receipts used to retire govemment debt, equals the amounts inplicit in the authorities' Siability Program for 2002-06, and equal to the 2006 share of GDP thereafter. 
Table 4. Grete: Indicators of External and Fingncial Vulnerability, 1997-2003 U/ (n percent of GDP, unless wherwise indicated)

\begin{tabular}{|c|c|c|c|c|c|c|c|c|}
\hline & \multirow[t]{2}{*}{1997} & \multirow[t]{2}{*}{1998} & \multirow[t]{2}{*}{1999} & \multirow[t]{2}{*}{2000} & \multirow[t]{2}{*}{2005} & \multirow[t]{2}{*}{2002} & \multicolumn{2}{|c|}{2003} \\
\hline & & & & & & & $\begin{array}{c}\text { Latest } \\
\text { Data }\end{array}$ & Date \\
\hline \multicolumn{9}{|l|}{ Exterzal indleators } \\
\hline Exports (annual percent change, in U.S. dodars) & 9.1 & 3.8 & 28.1 & 19,4 & 4.0 & -7.1 & $\cdots$ & $\cdots$ \\
\hline Imports (annual percent change, in U.S. dollans) & 10.6 & -1.5 & 13.7 & 14.9 & -2.5 & 5.4 & $\cdots$ & $\cdots$ \\
\hline Terms of trade (annual percent change) & 3.3 & 4.2 & 8.3 & 2.7 & 1.7 & -3.1 & $\cdots$ & $\cdots$ \\
\hline Current accoumt balance (settlensents basis) & -4.0 & -3.0 & -4.3 & -6.9 & -6.2 & -5.1 & $\cdots$ & $\ldots$ \\
\hline Capital and finmeial account bakance & 5.0 & 3.1 & 3.9 & 7.2 & 5.3 & 7.3 & $\cdots$ & $\cdots$ \\
\hline Of which : Inward portfolio irvestrnent (debl securities etc.) & 1.3 & 7.6 & 5.4 & 8.2 & 7.6 & 9.3 & $\cdots$ & $\cdots$ \\
\hline Inwand foreign direct investryent and othet utrvestinents & 1.3 & -2.3 & 3.7 & .2 .2 & -5.1 & 6.7 & $\cdots$ & $\cdots$ \\
\hline Official restaves (in U.S. dollars, tril lions, end of periad) & 12,595 & 17,458 & 18,122 & 13,424 & 5,1542 & 8,083 & 8,510 & Feb-03 \\
\hline Official restrves in months of imports GS & 5. & 7.6 & 6.1 & 3.9 & 1.5 & 2.4 & ... & m \\
\hline Tonal external debi & $\cdots$ & 55.4 & 55.5 & 73.0 & 69.2 & 68.2 & $\cdots$ & $\cdots$ \\
\hline Of which : Geaneral governintent debt $3 /$ & 25.1 & 25.4 & 26.6 & 22.1 & 6.5 & 3.7 & $\cdots$ & $\ldots$ \\
\hline Tọtal external debl to exports OSS (ratio) & $\ldots$ & 3.5 & 2.5 & 2.3 & 2.1 & 2.2 & $\cdots$ & $\ldots$ \\
\hline External interest payments to exports GS (in perøenti) & 12.6 & 14.3 & 16.7 & 10.5 & 10.4 & 9.9 & + & $\cdots$ \\
\hline External amortization payments to exports GS (in percent) & 349 & 34.0 & 12.4 & $\cdots$ & ,.. & $\cdots$ & $\cdots$ & $\cdots$ \\
\hline Excharge rate (per U.S. doltar, pertod average) 4 ) & 273.1 & 295.5 & 305.7 & 365.4 & 1.1 & 1.1 & 3.1 & $4 / 24 / 2003$ \\
\hline \multicolumn{9}{|l|}{ Financial market indicators } \\
\hline Public sector debt (Maastricht definition) & 108.2 & 105.8 & 105.1 & 106.2 & 107,0 & 104.9 & $\ldots$ & $\ldots$ \\
\hline Grek contriburion to euro 2rea $M 3$ (percent charge, 12-snonth basis) $5 /$ & 7.8 & 9.8 & 5.5 & 10.4 & 7,4 & -1.8 & 3.2 & Mar-03 \\
\hline Ptivate sector credil (pereent chasge, 12-nwont basis) & 15.3 & 15.0 & 14.2 & 27,6 & 24.8 & 16.9 & 17.2 & Mar-03 \\
\hline 12-month T-bil yietd & 9.5 & 12.0 & 9.4 & 7.2 & 4.1 & 3,5 & 2.4 & Mar -03 \\
\hline I2-month T-bill yield (real) & 3.8 & 6.9 & 6.6 & 3.9 & 0.4 & $-0,4$ & -1.4 & Mar-03 \\
\hline Stock market index & 1,480 & 2,738 & 5,535 & 3,389 & 2,592 & i,748 & 1,664 & $4 / 24 / 2003$ \\
\hline Share prices of tinanciai institutions & 2,303 & 5,799 & 50,165 & 7,307 & 4,788 & 2,688 & 2,473 & $4 / 24 / 2003$ \\
\hline Spread of 3-month money market rate with Gernany (percentage points, end of period) & 8.1 & 9.8 & 7.6 & 0.2 & 0.1 & 0.0 & B.0 & Mar-03 \\
\hline Spread of 10 -year bond with Germany (pereentage points, end of period) & 4.1 & 3.8 & 1.8 & 0.6 & 0.3 & 0.3 & 0.3 & $\mathrm{Mar}-03$ \\
\hline Flatucial sector risk factors & & & & & & $=$ & & \\
\hline Fortign exchatgge loars to the grivale sector (in millions of U.S. dollars) 6 f & 9,138 & 11,460 & $\pm 2,207$ & 14,679 & 5,406 & 6,723 & $\omega$ & $\cdots$ \\
\hline Share of fortigh exchantge loans in wita lending to the private sector 6/ & 30.6 & 31.9 & 34.4 & 34.9 & 10.2 & 7.4 & $\ldots$ & $\cdots$ \\
\hline Deposits in foreign exchange (in millions of U.3. dollars) $6 /$ & $29, \mathbf{2 4 0}$ & 38,611 & 31,118 & 35,661 & 19,603 & 17,858 & $\ldots$ & $\cdots$ \\
\hline Stare of foreign deposits in total deposits 6 & 29.5 & 35.2 & $\mathbf{3 0 , 9}$ & 39.3 & $2 \$ .8$ & 16.3 & $\ldots$ & $\cdots$ \\
\hline Share of teal estite sector in private credic & 17.3 & 17.8 & 19.5 & 19.9 & 26.9 & 24.5 & $\cdots$ &.+ \\
\hline Corrunercial banks' return on astets (2yter ax) & 0.7 & 0.8 & 2.4 & 1.4 & 1.0 & 0.5 &.-+ & $\cdots$ \\
\hline Itterest rate margin & 8.8 & 7.9 & 6.3 & 6.2 & 6.0 & 5.7 & $\ldots$ & $\cdots$ \\
\hline Share of nottperforming toans in rotal loans $7 /$ & 16.5 & 13.6 & 15.5 & 12.3 & 9.2 & B.1 & $\ldots$ & 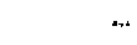 \\
\hline Share of nonperforming loans in total assets $7 /$ & 5.9 & 5.4 & 5.8 & 4.7 & 4.3 & $\cdots$ & $\ldots$ & $\cdots$ \\
\hline Risk-based capital asset ratio 8 & 10.3 & 10.2 & 16.2 & 13.6 & 12.5 & 11.69 & $\cdots$ & + \\
\hline \multicolumn{9}{|l|}{ Foreign carrency debt and bankfag atetor rating } \\
\hline Slandard \& Poor's & Mar-94 & Mar-97 & Dec-98 & Nov-99 & Mar-01 & $\mathrm{Jul}-\cos _{2} 10 \mathrm{l}$ & & \\
\hline Long werm & BBB- & B8B- & BBE- & A. & A & A & & \\
\hline Outlook & Stable & Positive & Positive & Positive & Positiva & Postitia & & \\
\hline Shott tetm & A-3 & A-3 & A-3 & A-1 & $A-1$ & A-l & & \\
\hline Moody's & May-94 & Dec-96 & Juk-99 & $\operatorname{Jan}=00$ & Aug-01 & Nor-02 & & \\
\hline Bonds and notbos & Baa] & Baal & $A 2$ & A2 & $A 2$ & Al & & \\
\hline Bark financial scrength rating & $\ldots$ & $\cdots$ & ... & $\mathrm{D}$ to $\mathrm{D}+$ & $\mathrm{D}+$ & c. & & \\
\hline$I B C A$ & Oct-9s & $\exists u n-97$ & Oct-99 & $J u j-00$ & Jun-01 & Jun -02 & & \\
\hline Long tetro & BBB- & BBB & B8B & A- & A & A & & \\
\hline
\end{tabular}

Salires: Bank of Greece, Monshly Steristical Bulletin; data provided by the euthorities; and IMf, Intemational Financial Statistlax.

1) The interpretation of some indicutors is affected by participation in EMU in 2001.

2 Oficial reserves declined in 2001 with EMU participation, due in large part to the redefinition of foreign ekehange rtserves and the fall in foceign exchamge reserve requirements for comunerial banis.

3/ Fom 2001, foreign debc includes only liabilities in nop-euro area currencies.

4/ Euras per U.S. dollar from 2001.

5/ Data prior to $200 !$ refer to growth of Greek liquidity measure M4N.

6/ As trom 2001, losns and deposits in eure and its nationel denominations are not inchudeo it foreipn exchange loans and fareign exchange deposits respectively.

t/ Daca refer to all commercial barles incorporated in Greece. Nonpectorming loans anc definted as all loans with interest and/or principal payments in arrears

tor tiree months or more, and include at: loans classifted at doubrtul by the berks thernselves.

8/ Dala refer to all commercial banks incorporated in Greece, Starting in 1998, data take also into account market risks.

9/ Septernber 2002.

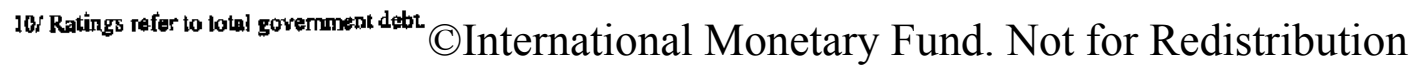


Table S. Greece: Summary of General Government Accounts, 1997-2003

(In percent of GDP)

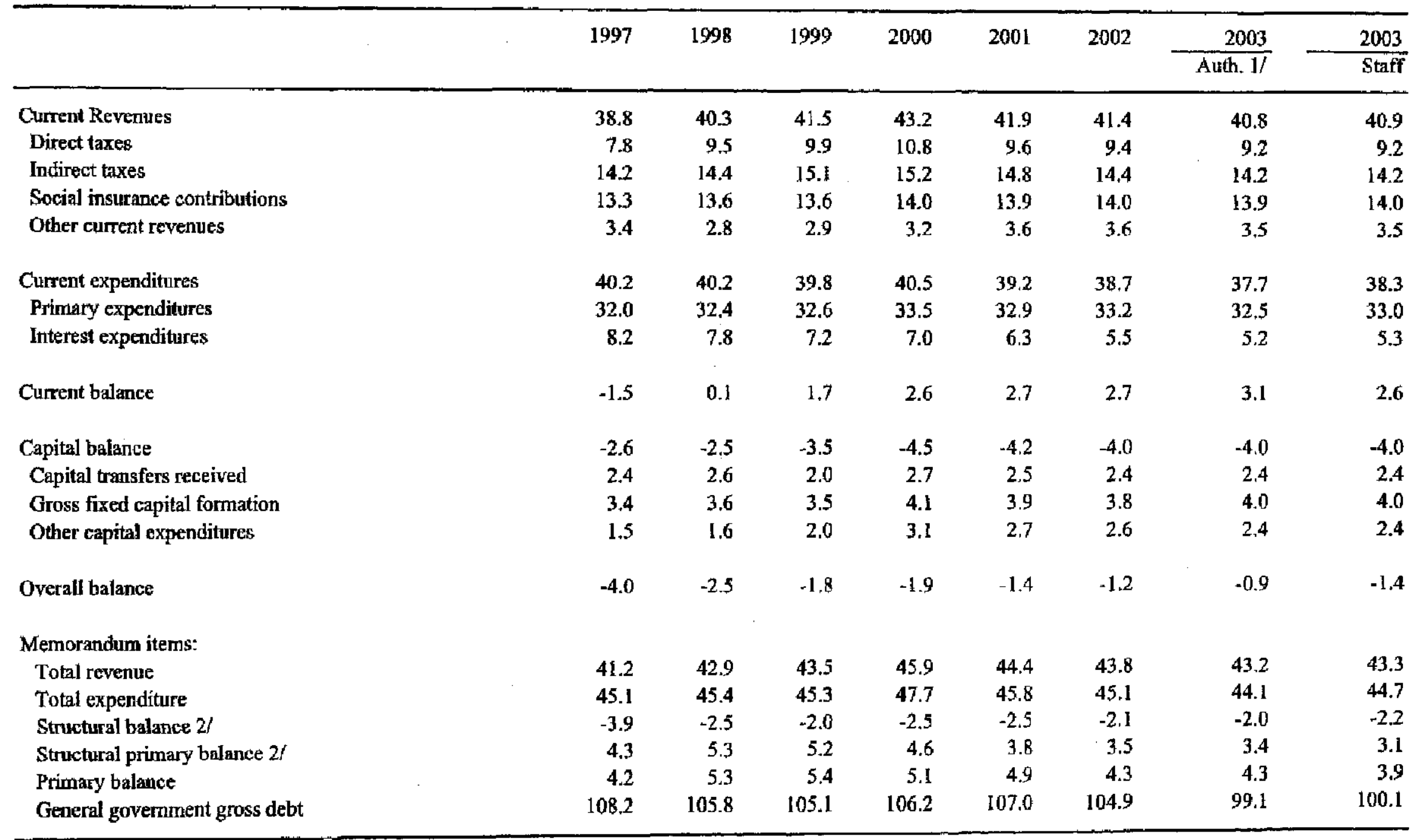

Sources: National Statistical Service; Ministry of National Economy; and Fund staff estimates and projections,

1/ Ministry of Economy and Finance March 2003 projection, which differs from the Stability Program for 2002-06 due to revised macroeconomic estimates for 1999-2002.

2/ Fund staff estimates, For 2001, excludes UMTS revenues equivalent to 0.4 percent of GDP. 
Figure 1. Greece: International Comparisons of Macroeconomic Performance, 1995-2003 1/
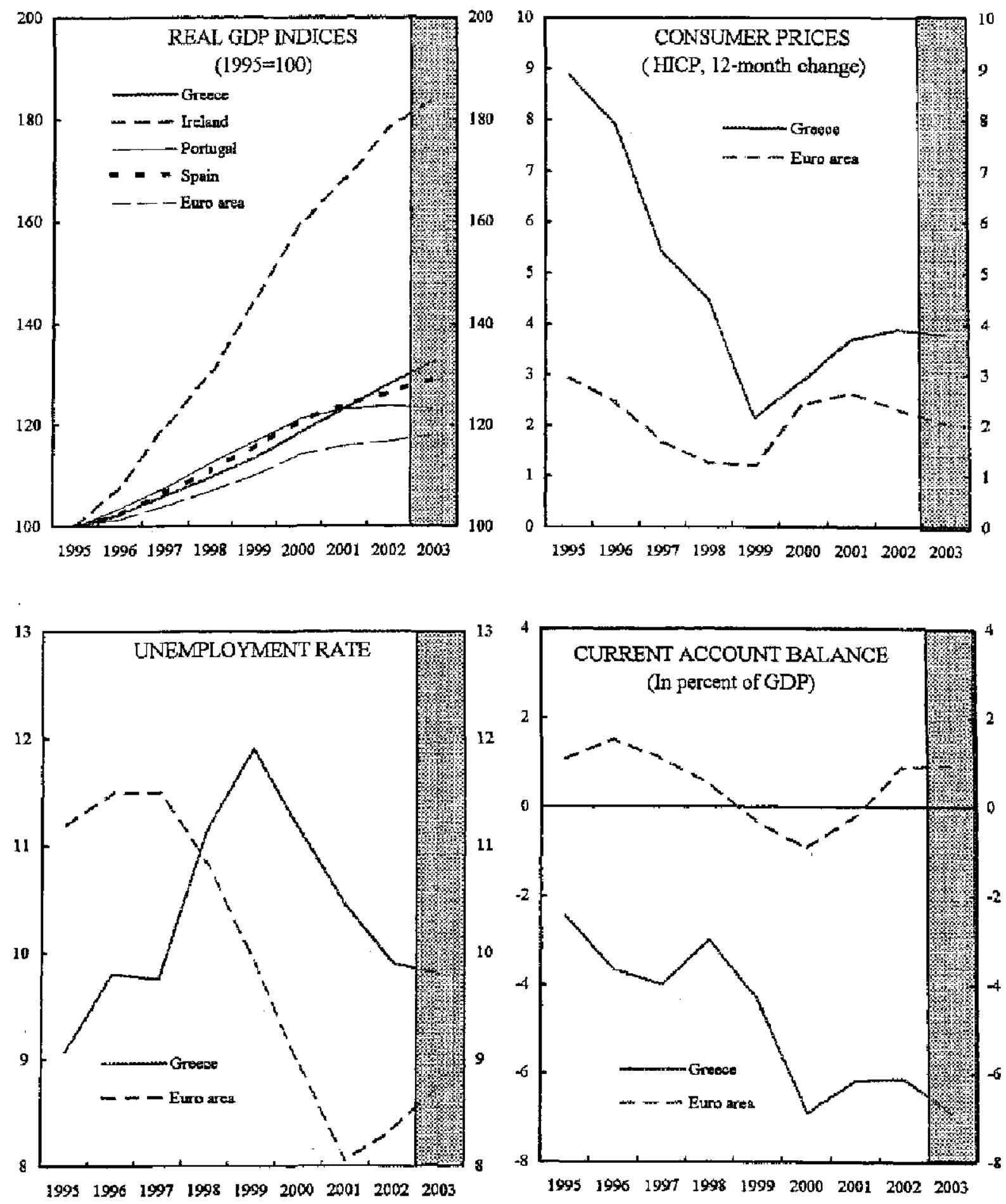

Source: IMF, World Economic Ouilook.

1/ Shaded areas show Fund staff projections. 
Figure 2. Greece: GDP Growth and Components' Contributions, 1995-2002 (Year-on-year change, in percent)
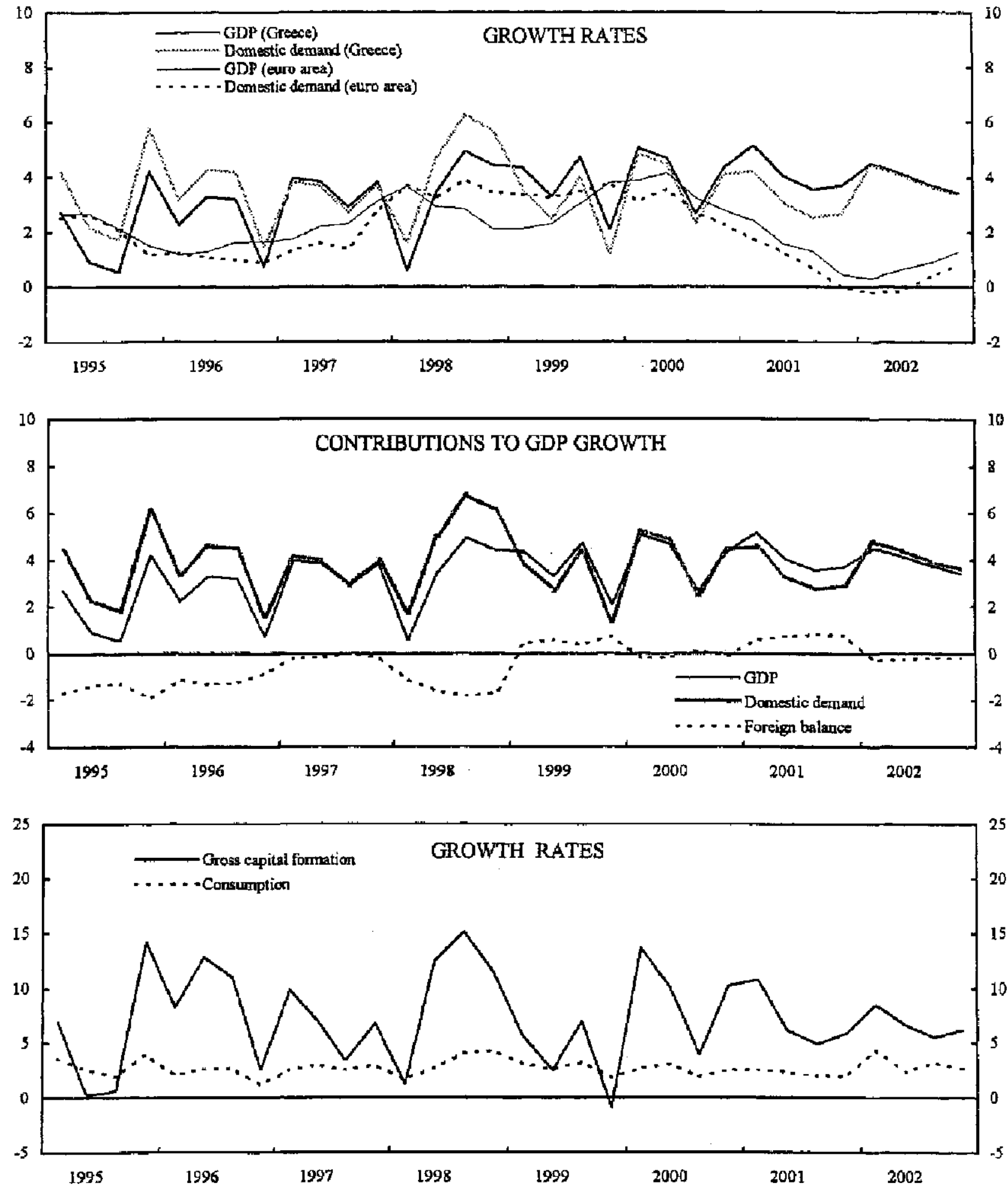

Sources: National Statistical Service; Ministy of National Economy; EU1 database; and Fund staff calculations. 
Figure 3. Greece: External Developments, 1995-2003 1/
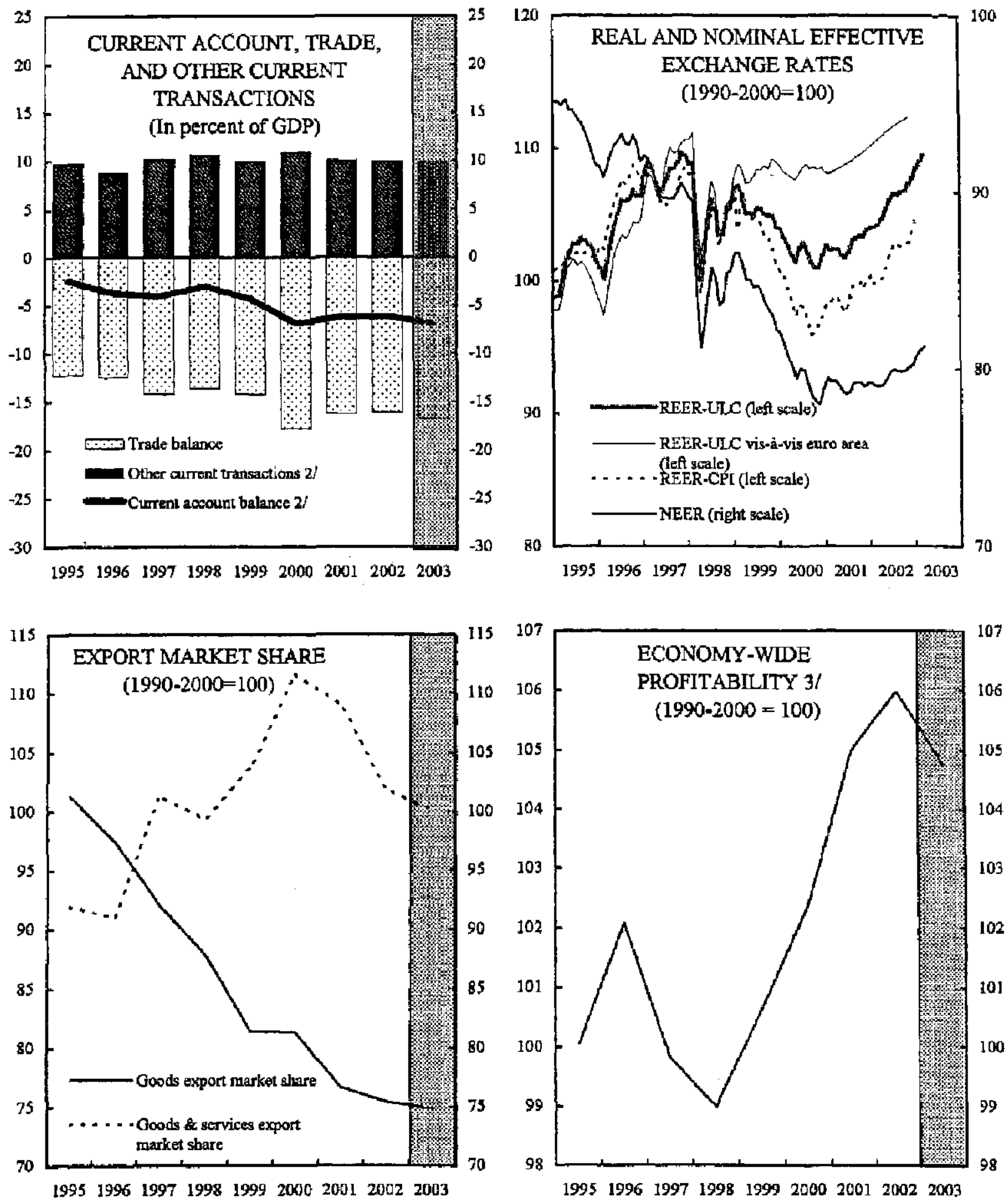

Sources: IMF, World Economic Outlook; and International Financial Statistics.

1/ Shaded areas show Fund staff projections.

2/ Including capital transfers.

3/ Ratio of GDP deflator to economy-wide unit labor costs. 
Figure 4. Greece: Credit Developments, 1995-2003

(In percent)
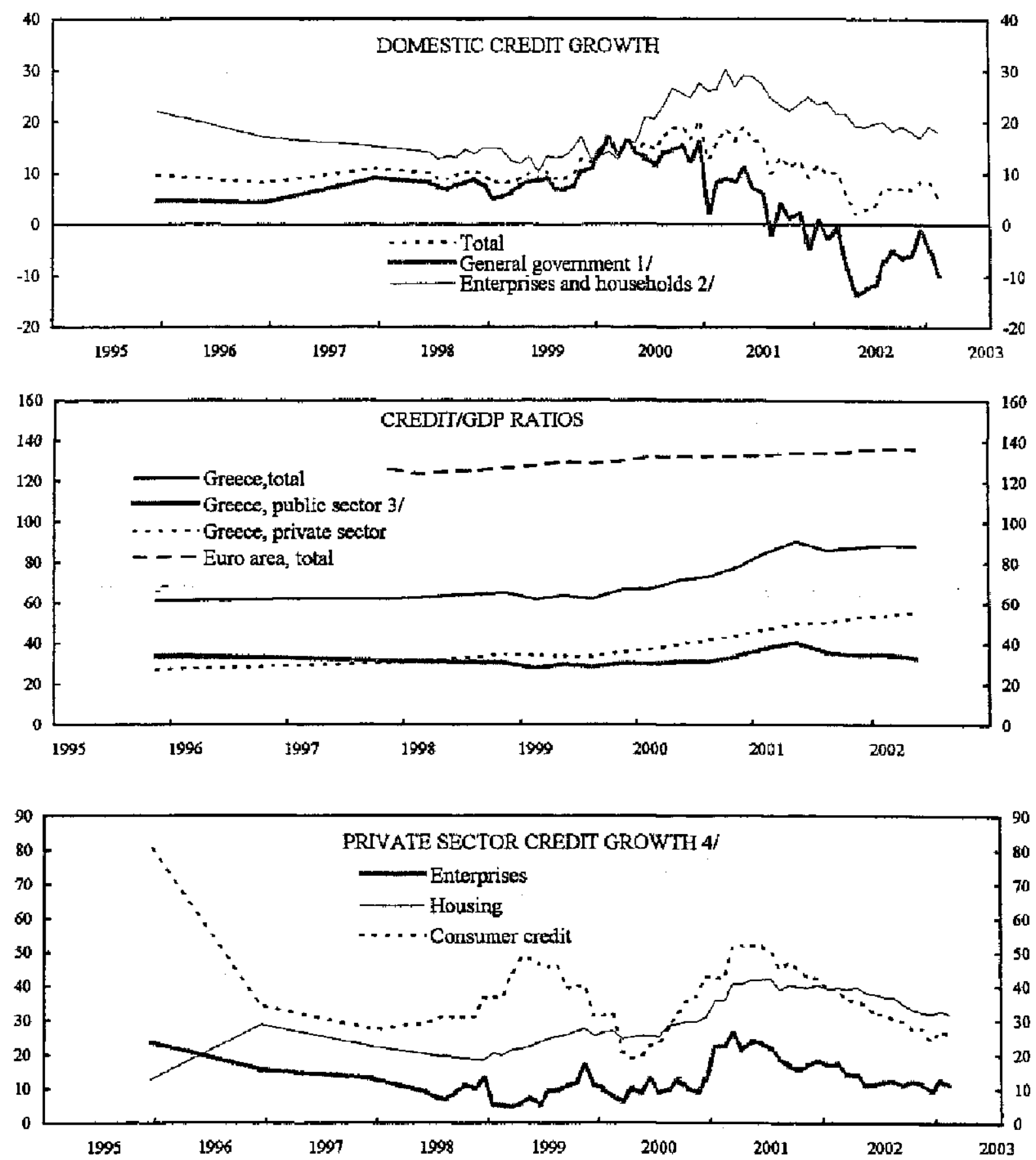

Sources; Bank of Greece, Bulletin of Conjunctural Indicators, and Monthy Statistical Bulletin ,

1/ Data prior to 1999 refer to public sector.

2/ Data prior to 1999 refer to private sector.

$3 /$ Excludes banks' holdings of government securities.

4/ Data prior to 2000 refers to commetcial bank credit. 
Figure 5. Greece: Entering Monetary Union-A Comparison of Monetary Conditions and Output Gaps, 1996-2003 1/2/
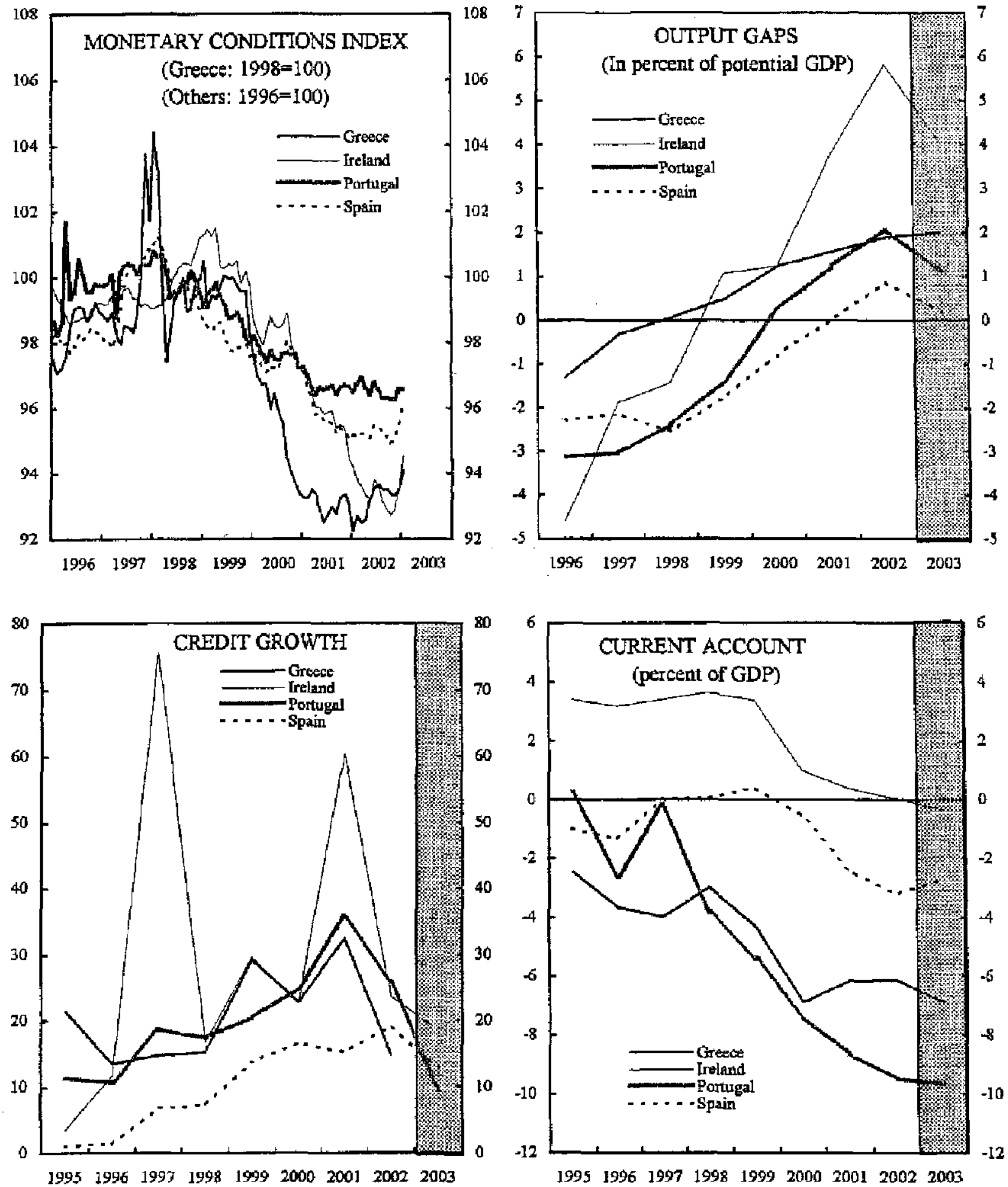

Sources: IMF, World Economic Outlook, International Financial Statistics, and Information Notice System. 1/ Reflecting their earfier euro entry, data for countries other than Greece are lagged two years (for example, 2000 corresponds to 1998 , etc.).

2/ Shaded areas show Fund staff projections. 
Figure 6. Greece: Asset Market Developments, 1995-2003
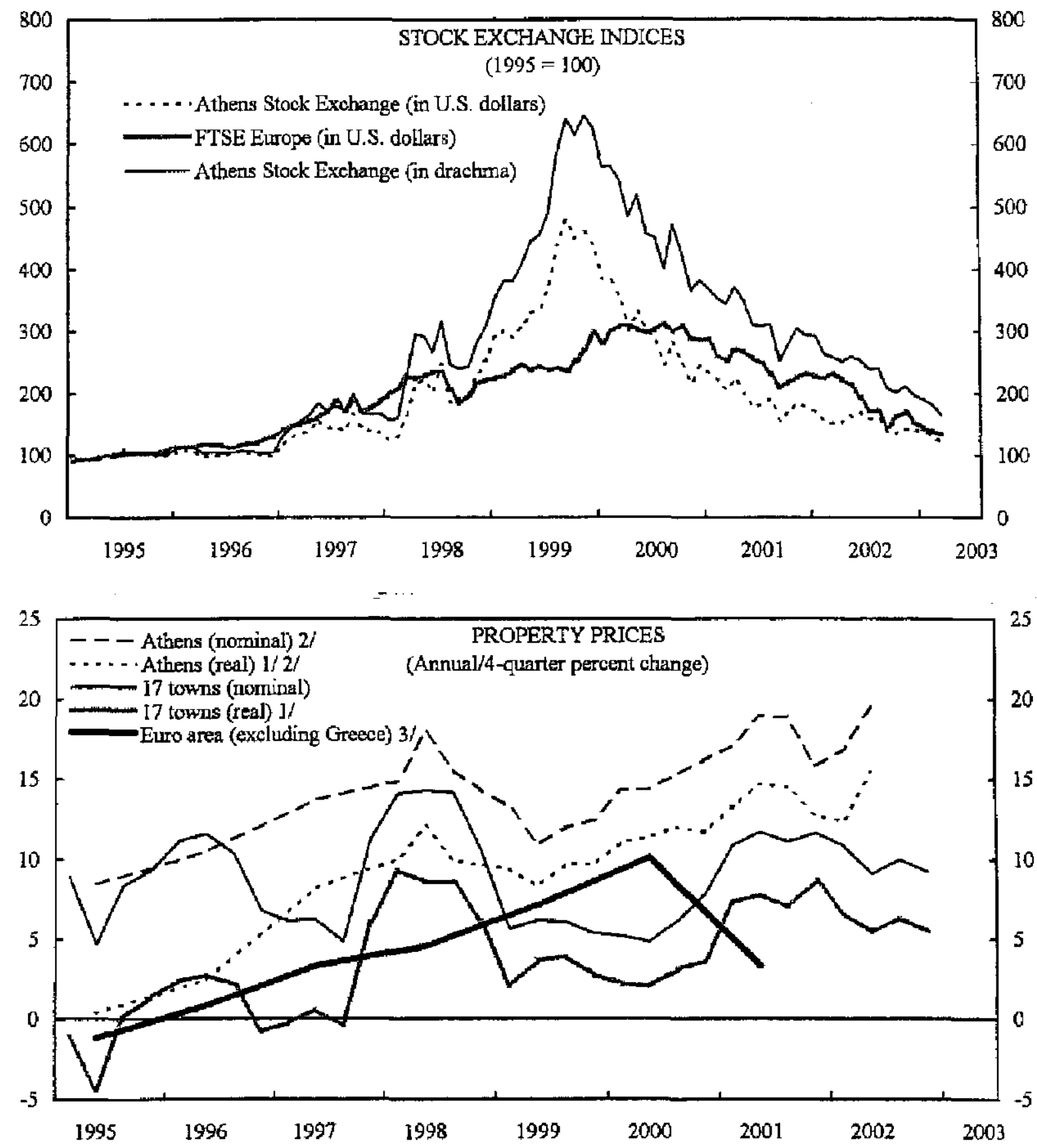

Sources: Bank of Greece; Bank for International Settlements; and Bloamberg.

1/ Deflated by consumer price inflation.

2/Annual until 1998.

3/ Arnual. 
Figure 7. Greece: General Government Deficit Changes and Contributing Factors, 1995-2002 (Percent of GDP)
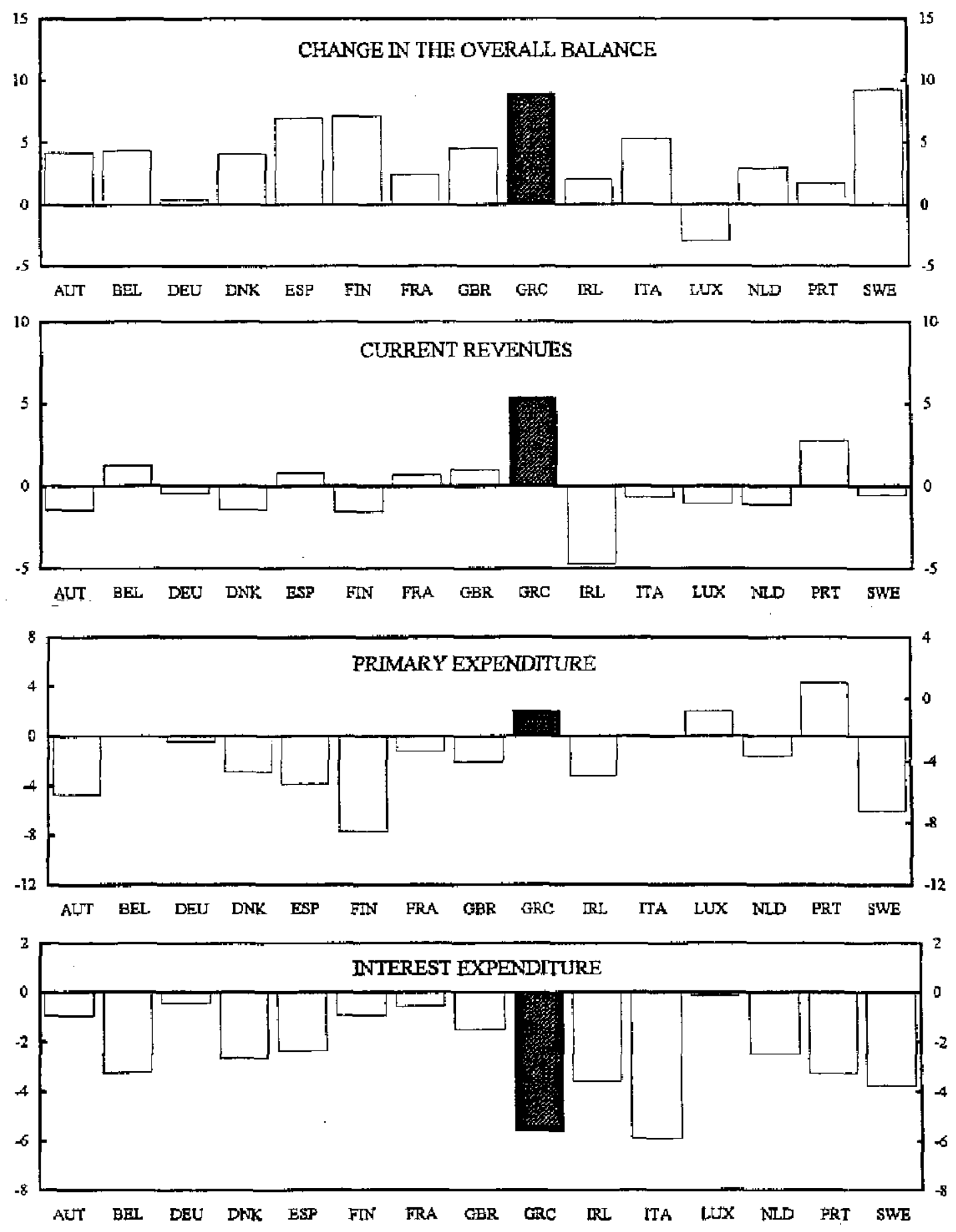

Scurce: MVF, World Economic Oullook. 


\section{GREECE: FUnd RELATIONS}

(As of March 31, 2003)

I. Membership Status: Joined 12/27/1945; Article VIII

II. General Resources Account:

SDR Million

823.00

500.55

322.45

Fund holdings of currency

Reserve position in Fund
III. SDR Department:

Net cumulative allocation

Holdings

Designation Plan

SDR Million
103.54
12.05
0.00

\% Quota

100,00

60.82

39.18

IV. Outstanding Purchases and Loans: None

V. Financial Arrangements: None

VI. Projected Obligations to Fund (SDR million; based on existing use of resources and present holdings of SDRs):

\begin{tabular}{lccccc}
\hline & & \multicolumn{4}{c}{ Forthcoming } \\
\cline { 2 - 6 } & 2003 & 2004 & 2005 & 2006 & 2007 \\
\hline Principal & & & & & \\
Charges/Interest & 1.21 & 1.60 & 1.60 & 1.60 & 1.60 \\
Total & 1.21 & 1.60 & 1.60 & 1.60 & 1.60 \\
\hline
\end{tabular}

VII. Exchange Rate Arrangernents:

Greece entered the final stage of European Economic and Monetary Union on January 1,2001 , at a rate of 340.750 Greek drachmas per 1 euro. Greece maintains restrictions on the making of payments for current international transactions vis-à-vis Iraq. These restrictions were notified to the Fund under Decision 144-(52/51) in EBD/90/304, $9 / 21 / 90$.

VIII. Article IV Consultation: Greece is on a 12-month consultation cycle; the last Article IV consultation discussions were concluded on February 22, 2002 (EBM/02/18).

IX ROsCs

Standard Code Assessment

Fiscal Transparency

Fiscal Transparency

Fiscal Transparency
Date of Issuance October 6, 1999

February 8, 2001

March 15, 2002
Document Number

SM/99/255

SM/01/25, Sup. 1

SM/02/32, Sup. 1 
X. Technical Assistance:

Year Dept. Purpose

1993 FAD Treasury Reform

Date

1993

MAE Central Bank Independence in the Context of the Maastricht Treaty

1994 MAE Development of Primary and Secondary Markets in September Government Securities

2002 STA Action plan and time frame for SDDS subscription June

XI. Resident Representative: None 


\section{GREECE: STATISTICAL ISSUES}

Greece has made substantial progress in recent years in statistical methodologies and compilation practices aimed at fulfilling its responsibilities as a member of the European Union and the euro area. Greece became the fifty-first country to subscribe to the International Monetary Fund's Special Data Dissemination Standard (SDDS) on November 8, 2002-it has taken flexibility options on the periodicity and timeliness of central government operations data on financing, which are released annually, and on the timeliness of the international investment position data. Subscription followed an IMF technical assistance mission from the Statistics Department in June 2002. Greece is also undertaking a data module of the Report on the Observance of Standards and Codes (ROSC), and a Statistics Department mission visited Athens from October 29-November 12, 2002.

Recent progress could form a sound basis from which further improvements can be achieved. Even though all statistics are readily available to the public, statistical presentations could be improved in most cases to facilitate analysis anc understanding and service to users could be further enhanced by dissemination of more detailed metadata including wider identification in press releases, and by publicizing contact persons. Most statistics do not provide the public with a clear statement of the revision policy. Furthermore, further progress is needed in shortterm data and in reconciliation across datasets.

\section{National accounts}

The scope of the national accounts produced by the National Statistical Service of Greece (NSSG) based upon the 1995 ESA extends beyond the recommended range of annual tables, and includes regional accounts, simplified provincial accounts, accounts for agriculture, detailed tables relating to environmental issues, and a Social Accounting Matrix (for 1997). However, in some cases, there is reliance on benchmark ratios that are old and the estimates of unrecorded activities are included implicitly as a result of using balancing procedures. In addition, limited quarterly national accounts estimates are available from the first quarter of 1970 to the third quarter of 2002; these rely more on econometric estimation than on actual data.

\section{Balance of payments and external trade}

The Bank of Greece (BoG), in cooperation with several European central banks, has been engaged for a number of years in a comprehensive revision of balance of payments data on a settlements basis consistent with the fifth edition of the Balance of Payments Manual (RPM5). Data for 1999 are the first available under the new system, with the BoG also providing estimates for 1997-98 (collected under the previous system, but compiled in the new categories). Monthly balance of payments data are reported to both the European Central Bank (ECB) and the IMF according to the timetable set by the ECB. Greece's balance of payments monthly data series present some departures from $B P M 5$, including: data do not include reinvested earnings nor undistributed branch profits; the basis for recording departs from accrual accounting as is typical with the use of bank settlements-based reporting 
systems; and data on interest payments for government debt are also reported on a cash basis. A full international investment position-external assets and liabilities-for all sectors of the economy has been submitted to the IMF for the years 1998-2001. The BoG is disseminating monthly data on the template on international reserves and foreign currency liquidity within 21 days after the end of the reference month. Despite the new settlements-based reporting system, significant differences remain in comparison to national-accounts-based current account data, with sizable differences in changes (and even in direction) of the current account and its components in recent years.

\section{Government accounts}

Monthly data for the budgetary central government are very aggregated. Revenue, expenditure, and financing definitions are broadly in line with the 1986 GFS Manual. The quality and timeliness of the data on other public entities, including social security funds and local governments, are poor.

The NSSG compiles data on general government revenue, expenditure, and deficit on an accrual basis in the context of the ESA95 Transmission Program and of the Excessive Deficit Procedure. The absence of financing data (Greece has a derogation for financial accounts reporting until 2005) impedes elementary checking of the consistency of the data, including reconciliation between the government deficit and debt, and between government statistics and the statistics of other economic sectors. Greece tracitionally carries out substantial capital injections, whose nature must be carefully monitored in order to determine the proper statistical treatment (above or below the line).

Recently, the fiscal accounts prepared by the authorities were significantly revised following a review by Eurostat. Revisions involved reclassification of certain below-the-line transactions as expenditures, which increased estimates of the fiscal deficit. Also, government debt was increased, as debt issued by special purpose financing vehicles was added to debt stocks. As a result, the general government debt ratio was revised upward by some 8 percentage points of GDP.

Greece's annual government finance statistics on an accruals basis are published in the Supplement to the 2002 GFS Yearbook, which contains the statistics of selected countries according to the GFSM 2001 methodology. No sub-annual GFS data are reported for publication in IFS.

\section{Monetary accounts}

Upon Greece's participation in the euro area, the BoG successfully transitioned to compiling monetary statistics in accordance with ECB requirements. Monetary statistics for publication on Greece's International Financial Statistics (IFS) page have been revised for consistency with the other euro-area countries. Data reporting is timely. However, reporting discrepancies among banks' bilateral positions suggest improvements could be made in the accuracy and reliability of the source data used to compile monetary statistics; interbank reporting 
discrepancies in Greece's monetary statistics are not only large in stock terms (16:6 percent of total MFI deposits during January 1999-April 2002, compared with 0.2 percent euro-area average), but also volatile (13.6 percent standard deviation). In addition, systematic crosschecks between monetary statistics and other data sets are not undertaken. The data ROSC module for Greece, conducted during October/November 2002, noted the following additional areas where Greece's monetary statistics are not fully in iine with the IMF's Monetary and Financial Statistics Mamual: (i) positions in financial derivatives and claims on the central government are not separately identified; (ii) some deposits are not accurately classified; and (iii) accrued interest is excluded from outstanding amounts for loans and deposits recorded in the balance sheet.

\section{Labor market}

A more detailed quarterly labor force survey, with an enlarged sample size and capable of generating data on an EU-barmonized basis, has been used since the fall of 1998. However, the interpretation of labor market developments continues to be hampered by difficulties in covering immigrants, which constitute, compared with other EU countries, a relatively large fraction of the Greek labor market. Data on earnings have not been produced since 1998.

\section{Short-term data}

The recent publication of quarterly national accounts is an important improvement in this area. However, other high-frequency indicators for economic surveillance (including retail sales, industrial production, wholesale prices, and other indices) are at times based on out-ofdate benchmark ratios and reporting delays seriously undermine the usefulness of these data. Source data and statistical techniques could be strengthened for prices, and source data improved for government finance statistics.

\section{Advance release calendars}

The NSSG has announced an advance publications schedule for all statistical releases. 
Greece: Core Statistical Indicators

(As of April 24, 2003)

\begin{tabular}{|c|c|c|c|c|c|c|c|c|c|c|c|c|}
\hline & $\begin{array}{c}\text { Exchange } \\
\text { Rates }\end{array}$ & $\begin{array}{c}\text { International } \\
\text { Reserves }\end{array}$ & $\begin{array}{l}\text { Central } \\
\text { Bank } \\
\text { Balance } \\
\text { Sheet }\end{array}$ & $\begin{array}{l}\text { Reserve/ } \\
\text { Base } \\
\text { Money }\end{array}$ & $\begin{array}{l}\text { Brond } \\
\text { Money }\end{array}$ & $\begin{array}{l}\text { Interest } \\
\text { Rates }\end{array}$ & $\begin{array}{l}\text { Consumer } \\
\text { Price } \\
\text { Index }\end{array}$ & $\begin{array}{l}\text { Exports/ } \\
\text { Iraports }\end{array}$ & $\begin{array}{l}\text { Current } \\
\text { Accoumt } \\
\text { Balance }\end{array}$ & $\begin{array}{c}\text { Central } \\
\text { Government } \\
\text { Balance }\end{array}$ & GDP/GNP & $\begin{array}{c}\text { External } \\
\text { Public } \\
\text { DebtDebt } \\
\text { Service }\end{array}$ \\
\hline $\begin{array}{l}\text { Date of Latest } \\
\text { Observation }\end{array}$ & $04 / 24 / 03$ & March 2003 & March 2003 & March 2003 & March 2003 & $04 / 24 / 03$ & $\begin{array}{l}\text { March } \\
2003\end{array}$ & \begin{tabular}{|l} 
February \\
2003
\end{tabular} & \begin{tabular}{|l} 
February \\
2003
\end{tabular} & \begin{tabular}{|l} 
February \\
2003
\end{tabular} & $\begin{array}{l}4^{\text {th }} \text { quarter } \\
2002\end{array}$ & 2002 \\
\hline Date Received & $04 / 24 / 03$ & $04 / 1] / 03$ & $04 / 24 / 03$ & $04 / 24 / 03$ & $04 / 24 / 03$ & $04 / 24 / 03$ & $04 / 14 / 03$ & $04 / 21 / 03$ & $04 / 11 / 03$ & $04 / 10 / 03$ & $02 / 20 / 03$ & $02 / 15 / 02$ \\
\hline $\begin{array}{l}\text { Frequency of } \\
\text { Data }\end{array}$ & Daily & Monthly & Monthly & Monthly & Monthly & Daily & Monthly & Monthly & Monthly & Monthly & Quarterly & Anthually \\
\hline $\begin{array}{l}\text { Frequency of } \\
\text { Reporting }\end{array}$ & Daily & $\begin{array}{l}\text { Monthly; or } \\
\text { when } \\
\text { requested }\end{array}$ & Montbly & Monthly & Monthly & Daily & Monthly & Monthly & Monthly & Monthly & Quarterly & Annualty \\
\hline $\begin{array}{l}\text { Source of } \\
\text { Update } 1 / \\
\end{array}$ & $\begin{array}{l}\text { Reutersi } \\
\text { Bloomberg }\end{array}$ & BoG & BoG & BoG & $\mathrm{BoG}$ & $\begin{array}{l}\text { Reuters/ } \\
\text { Bloomberg }\end{array}$ & NSSG & $\mathrm{BoG}$ & BoG & MEF & Bloomberg & $\mathrm{BoG}$ \\
\hline $\begin{array}{l}\text { Mode of } \\
\text { Reporting }\end{array}$ & Electronic & Electronic & Electronic & Electronic & Electronic & Electronic & Electronic & Electronic & Electronic & Electronic & Electronic & $\begin{array}{l}\text { Electronic/ } \\
\text { statistical } \\
\text { bulletin }\end{array}$ \\
\hline Confidentiality & None & None & None & None & None & None & None & None & None & None & None & None \\
\hline $\begin{array}{l}\text { Frequency of } \\
\text { Publication }\end{array}$ & Daily & Monthly & Monthly & Monthly & Monthly & Daily & monthly & Monthly & Monthly & Monthly & Quarterly & Monthly \\
\hline
\end{tabular}

W BoG = Bank of Greece; MEF = Ministry of Economy and Finance; NSSG = National Statistical Service of Greece. 


\section{Greece: General Government and ExTernal DebT Sustainability ${ }^{1}$}

1. This appendix presents the staff's baseline projections for Greece's general government and external debt and compares them to alternative scenarios, which are based on shocks to various underlying variables. The shocks are expressed as temporary deviations from the baseline (the staff's spring 2003 World Economic Outlook projections), using shocks relative to historical averages (i.e., the past 10 years) of the variable under consideration, without taking dynamic feedback effects into account.

\section{General government debt sustainability}

2. The baseline scenario envisages a gradual reduction of the high level of public debt in Greece. Under the baseline projection-which assumes that the structural primary surplus in 2004-07 remains constant at its estimated 2003 level-the public debt ratio would decline from a 105 percent of GDP at end-2002 to about 94 percent of GDP at end-2007 (Table 1). The decline reflects foremost continued primary surpluses (although the surpluses decline as the positive output gap closes over the medium term). In the projections, growth effects largely balance projected interest payments. However, the debt dynamics is negatively affected by continued recourse to below-the-line debt creating flows, as envisaged in the authorities' Stability Program (see also Section II.C of the main text).

\section{The shocks to the baseline illustrate potential risks, even if the shocks would} typically not result in substantial increases of the present high debt ratio. If historical averages were repeated for real GDP growth, real interest rates, and the primary balance, the resulting debt ratio would be 7 percentage points higher by the end of 2007 , compared with the baseline. The difference refiects foremost a stronger projected primary balance than observed over the past 10 years (although the baseline incorporates some weakening of the primary balance from its 2002 level). The important role of the primary balance is also illustrated by the single variable shocks, where a two standard deviation shock in 2003-04 to historical averages would preclude any decline in the debt ratio over the medium term (see test 4). However, the risks in this regard seem relatively remote, as fiscal deficits implied by these primary balance shocks would exceed the Stability and Growth Pact's 3 percent ceiling by a wide margin. After euro-area entry, the small size of foreign-currency denominated debt makes public debt relatively immune to a sharp exchange rate depreciation (test 6 ).

4. These stress tests highlight some of the risks to the public finances, and these are accentuated by longer-term fiscal pressures related to population aging. Within monetary union, some of the liquidity risks associated with the refinancing of high public debt levels are likely to be less pronounced-although it is also worthwhile to note that statistical weaknesses do not allow an accurate and timely picture of the general government's gross financing needs (see Appendix $\mathrm{I}$ ). Over the longer term, public debt dynamics could be severely affected by pension expenditures: absent further reforms, these are set to rise by more in Greece than in any other industrial country. These longer-term

${ }^{1}$ This Appendix reports standardized stress tests. 
risks, discussed in the main text, are not captured within the horizon of the standardized stress tests reported in this appendix.

\section{External debt sustainability}

5. The baseline scenario envisages a steady rise in the external debt-to-GDP ratio to above 80 percent of GDP by 2007 (see Table 2). The underlying assumptions are consistent with the macroeconomic scenario of the spring $2003 \mathrm{WEO}$. The rise in the external debt ratio reflects persistent, sizable external current account deficits-while the "automatic debt dynamics" (related to the differential between nominal growth and interest rates) tends to reduce the debt ratio. The debt projections assume no additional international portfolio diversification after 2003; further diversification (from Greece's current level, which is considerably lower than in several smaller incustrial countries) would add to the gross debt levels relative to the baseline scenario.

6. The stress tests reveal several risks to the baseline scenario, even if some of these are attenuated by monetary union. If historical averages in key economic variables of the last ten years prevailed during the projection period (test 1), the ratio of external debt over GDP would be more than 15 percentage points higher by 2007 . This reflects in part relatively high growth and inflation projected for 2003 , resulting in a repeat of the favorable automatic debt dynamics estimated for 2002. More generally, the baseline incorporates somewhat higher growth (albeit at a slower rate than observed over the past five years) and higher projected U.S. dollar-denominated deflator increases (affected by WEO exchange rate assumptions). According to the single-variable stress tests (tests 2-5), the debt ratio would not be significantly different from the baseline scenario, with the notable exception of test 4 : an adverse shock to the GDP deflator (in U.S. dollar, which was historically quite volatile) for two years would cause the ratio to rise to almost 130 percent of GDP by 2007 . However, the shock does not seem likely in the euro-area context: test 4 assumes that the denominator of the debt-to-GDP ratio would decline sharply (in view of the fall in the GDP deflator by about 15 percentage points per annum during 2003-04), while the numerator (i.e., the external debt stock) would not be affected by the shock-an implausible dichotomy when foreign debt is predominantly denominated in euros and domestic deflation is unlikely. ${ }^{2} \mathrm{~A}$ combined adverse shock (test 6) to some extent picks up the same effect. In contrast, a strong depreciation of the euro does not have significant effects on the external debt-to-GDP ratio. This reflects the low share of non-euro denominated external debt, which is estimated at 7.5 percent of total external debt outstanding following Greece's euro-area membership.

\section{The rising debt ratio in the baseline scenario and additional pressures} highlighted, among others, in the stress tests underscore the risks of present macroeconomic trends in Greece. Related policy issues are discussed in the main text.

\footnotetext{
${ }^{2}$ The historical volatility in the deflator was, to an important extent, driven by exchange rate movements-while test 4 assumes implicitly that the shock occurs to domestic inflation. As test 7 illustrates, an exchange rate shock would have comparatively limited effects on external debt ratios, since most of Greece $s$ external debt is denominated in euros.
} 
Tabje 1. Greece: Public Secior Debt Sustainability Franework ${ }_{+}$1997-2007

(In percent of GDP, unless otherwise indicatcd)

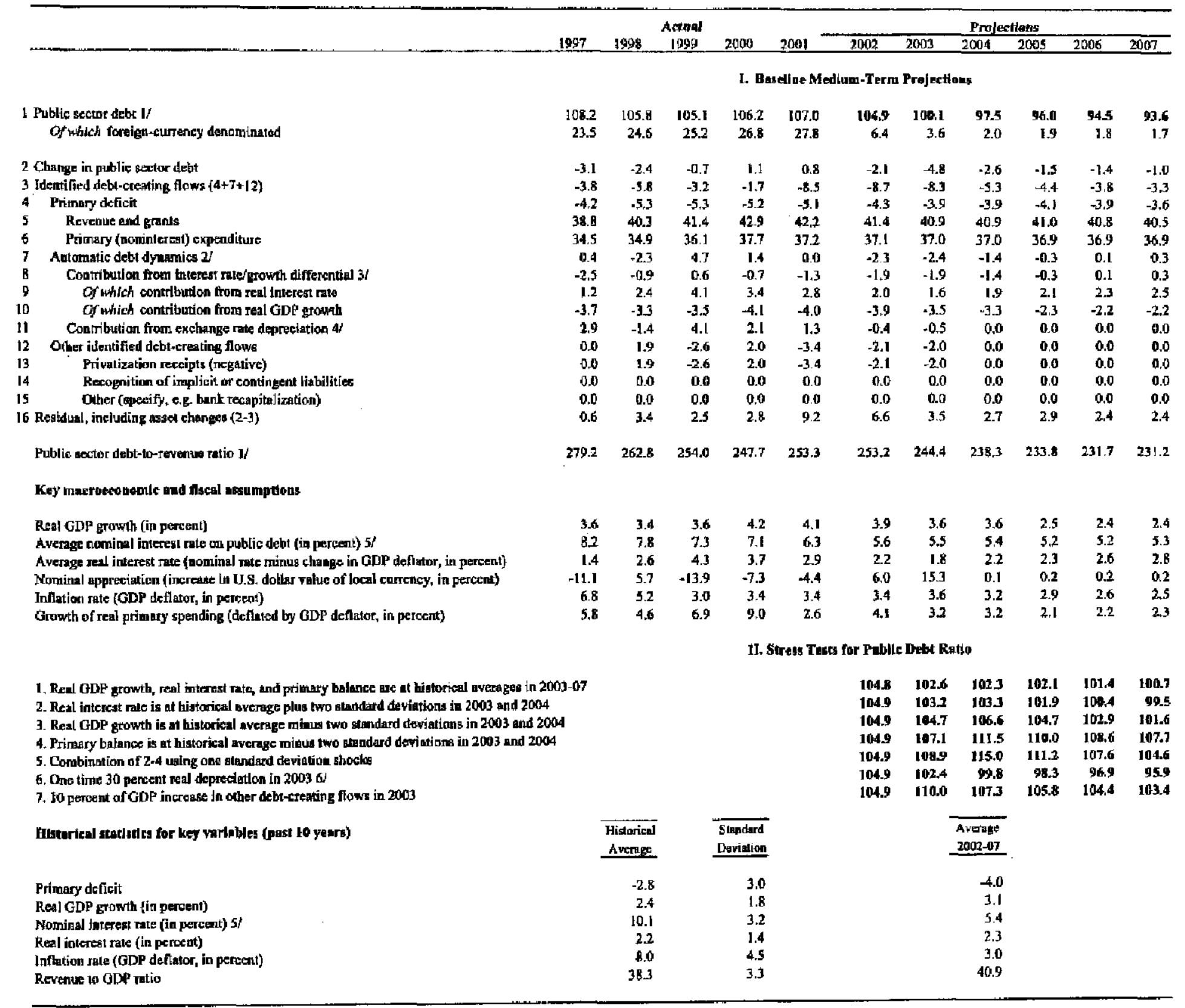

1/ Fublic cecioc here cowers the Greck general government

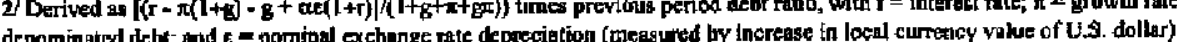

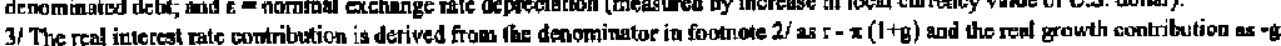

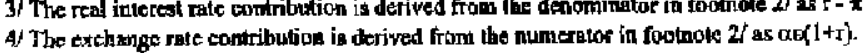

5/ Derived as nominal interest expendilure divided by previous period debr stock.

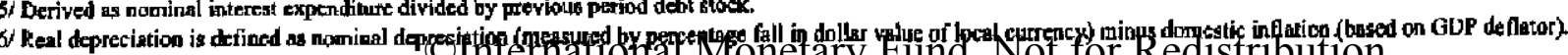




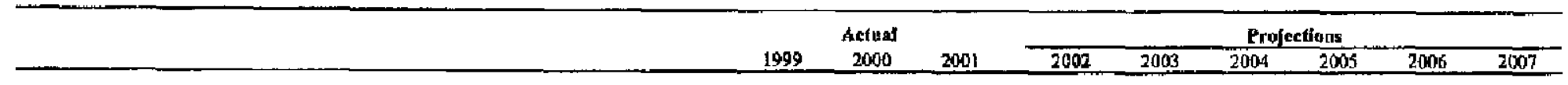

\section{Erternal debr}

2 Change in exlemal debt

3 Identified external debt-ereating flows $(4+8+11)$

Current account deficit, excluding interest payments.

Deficit in babance of goods and services

Exports

Imports

Net nondebr creating capital inflows (negative)

Net foreign direct investment, equity

Net portfolio investrinent, equity

Automatic debt dynamics 1 /

Contribution from nominal integrest tate

Contribution from real GPP growth

Contribution from price and exchange nate changes 2

14 Residwal, incl. change in gross fortign assets (2-3)

External debt-to-experts tatio (in percent)

Key macreecomomic and extermal sssumptions

Real GDP stowth (in percent)

Exchange mite appreciation (U.S. doller value of local currency, change in percenil)

GDP deflator in U.S. dollers (change in perceni)

Noninal external interest rate (in perceni)

Growth of exports (U.S. dollar terns, in percent)

Growth of imports (U.S. dollar terms, in percent)

55.4
1.1
2.9
1.7
8.5
19.9
28.4
2.2
0.0
-2.2
-1.0
2.3
-1.9
-1.5
-1.8

1. Raseline Medium-Term Prajections

$\begin{array}{rrrrrrr}69.2 & 70.1 & 71.5 & 73.7 & 76.5 & 79.8 & \mathbf{8 0 . 5} \\ -3.9 & 0.9 & 1.4 & 2.2 & 2.8 & 2.3 & 1.8 \\ -0.4 & 1.0 & 1.7 & 2.2 & 2.8 & 2.3 & 1.8 \\ 3.5 & 4.0 & 4.7 & 4.3 & 4.0 & 3.5 & 3.0 \\ 9.6 & 8.5 & 8.8 & 8.5 & 8.2 & 7.6 & 7.1 \\ 25.6 & 22.4 & 23.6 & 23.7 & 23.8 & 24.3 & 24.9 \\ 35.2 & 30.8 & 32.4 & 32.2 & 32.0 & 31.9 & 32.0 \\ -1.5 & 0.0 & 0.0 & 0.0 & 0.0 & 0.0 & 0.0 \\ 0.8 & 0.0 & 0.0 & 0.0 & 0.0 & 0.0 & 0.0 \\ 0.7 & 0.0 & 0.6 & 0.0 & 0.0 & 0.0 & 0.0 \\ -2.4 & -3.0 & -2.9 & -2.1 & -1.2 & -1.2 & -1.2 \\ 2.7 & 2.2 & 2.2 & 2.3 & 2.4 & 2.4 & 2.5 \\ -2.9 & -2.4 & -2.0 & -2.4 & -1.8 & -1.8 & -1.8 \\ -2.2 & -2.7 & -3.1 & -2.0 & -1.8 & -1.9 & -1.9 \\ -3.4 & -0.1 & -0.3 & 0.0 & 0.0 & 0.0 & 0.0 \\ & & & & & & \\ & & & & & \end{array}$

2790

282.6

269.9

313.2

302.7

321.7

324,4

323.9

$\begin{array}{rrrrrrrrr}3.6 & 4.2 & 4.1 & 4.0 & 3.6 & 3.6 & 2.5 & 2.4 & 2.4 \\ -3.4 & -16.1 & -4.3 & 5.4 & 15.3 & 0.1 & 0.2 & 0.2 & 0.2 \\ -0.5 & -13.2 & -1.1 & 9.3 & 19.5 & 3.0 & 2.7 & 2.7 & 2.6 \\ 4.4 & 4.4 & 3.8 & 3.5 & 3.9 & 3.4 & 3.4 & 3.3 & 3.3 \\ 40.2 & 17.6 & 2.1 & -0.9 & 30.7 & 6.8 & 5.8 & 7.5 & 7.6 \\ 129.1 & 16.8 & -1.1 & -0.4 & 30.2 & 5.8 & 4.7 & 4.9 & 5.3\end{array}$

\section{Stress Tests for External bebt Ratto}

rical

1. Real GDP growth, nominal interest rate, dollar deflator, nonimterest current accoumt, and noth
2. Nominal interest rate is at historical average plus two standard deviations in 2003 and 2004

3. Real GDP growth is at historical average minus two standard deviations in 2003 and 2004

4. Change in U.S. dollar GDP deflator is at bigtorlcal average minus two slanderd deviations in 2003 and 2004

5. Noninterest carrent acconnt is at historical average minus two standard deviations in 2003 and 2004

6. Combination of $2-5$ using one standard devistion shocks

7. One time 30 percent nominal depseciation in 2003

Historicar atofistics for key varlables (past 10 years)

$\overline{\text { Historical }}$

Standard

70.1

$\mathbf{8 2 . 9}$

86.3

$89.8 \quad 93.4$

$93.4 \quad 97.0$

$70.1 \quad 74.7$

75.4

78.2
83.0

85.1

85.1
127.0

82.2

$70.1 \quad 160.0$

74.193 .5

123.5

77.

80.181 .9

$79.1 \quad 74.3$

76.5

79.2

81.5

83.2

Cutrent account delicit, excluding interest payments

Net nondebl creatteg copital inflows

Notninal externa] interest rate (in percent)

Real GDP growth (in pereelts)

GDP deflator in U.S. dollars (change in percent)

\section{Average}

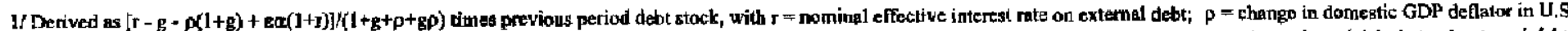

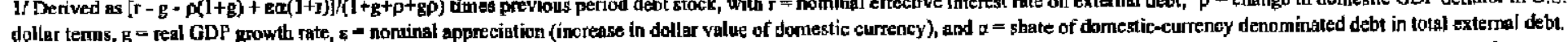

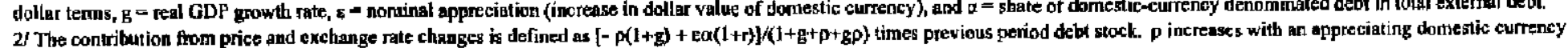
( $>>0)$ and rising inflation (based on GDP deflator). 
Staff Statement for the 2003 Article IV Consultation Discussion with Greece on May 16, 2003

The following additional information was received since the circulation of the staff report. This does not alter the thrust of the staff appraisal.

- GDP growth in the first quarter of 2003 remained strong. As noted in Mr. Vittas? buff, preliminary estimates indicate GDP growth of 4.3 percent (year-on-year) in the first quarter, driven by strong growth in investment and household consumption. Exports, however, recorded a further decline.

- Inflation declined markedly in April. For the harmonized consumer price index (HICP), inflation fell from 3.9 percent (year-on-year) in March to 3.3 percent in April, led by a deceleration of housing and energy prices. The deceleration was more pronounced than in the euro area, and the hcadline HICP differential narrowed to 1.2 percent (from 1.5 percent in March). Core inflation remained essentially unchanged at just over 3 percent.

- In contrast with these positive economic developments, cash data indicate an unexpectedly large budget gap for the central government in the first quarter of 2003, due to high expenditure growth. With strong economic growth, tax revenues increased solidly. However, primary spending at the ordinary budget level rose by 25 percent year-on-year in the first quarter. While temporary factors played some role, the results point to budget risks that may, if not addressed, be even larger than indicated in the staff report. Additional budget risks relate to the government's approval of substantial increases in permanent and part-time civil service employment, although it is unclear, at this stage, when and to what extent these plans will be implemented. 
Public Information Notice (PIN) No. 03/68

FOR IMMEDIATE RELEASE

June 11, 2003
International Monetary Fund $70019^{\text {th }}$ Street, NW

Washington, D. C. 20431 USA

\section{IMF Concludes 2003 Article IV Consultation with Greece}

On May 16, 2003, the Executive Board of the International Monetary Fund (IMF) concluded the Article IV consultation with Greece. ${ }^{1}$

\section{Background}

The economic expansion that began in the mid-1990s has continued unabated, with some employment gains in 2002 for the first time in four years. Gross Domestic Product increased by 4 percent in 2002, well above the EU average, but external imbalances remained large. High capacity utilization, EU transfers, and preparations for the 2004 Olympics underpinned investment, while private consumption was supported by sizable increases in household incomes. Domestic demand was also boosted by continued rapid credit growth, driven by historically low interest rates and recent financial liberalization. The unemployment rate declined but, at 9.7 percent in the last quarter of 2002, was still higher than in most euro-area countries. With a further loss in export market shares, the external current account deficit remained above 6 percent of GDP, one of the largest deficits among industrial countries.

Divergent cyclical positions and relatively high labor cost increases kept inflation well above the euro-area average. Consumer price inflation averaged close to 4 percent in 2002, and the inflation differential vis-à-vis the euro area exceeded 1.5 percentage points. Relatively high wage increases, not fully compensated by relative gains in productivity, and the euro

\footnotetext{
${ }^{1}$ Under Article IV of the IMF's Articles of Agreement, the IMF holds bilateral discussions with members, usually every year. A staff team visits the country, collects economic and financial information, and discusses with officials the country's economic developments and policies. On return to headquarters, the staff prepares a report, which forms the basis for discussion by the Executive Board. At the conclusion of the discussion, the Managing Director, as Chairman of the Board, summarizes the views of Executive Directors, and this summary is transmitted to the country's authorities.
}

Washington, D.C. 2043 * Telephone 202.623-7100 - Fox 202.62336772. Wwwim.oro 
appreciation have led to a weakening of cost and price competitiveness since Greece joined the euro area in 2001.

Notwithstanding strong economic growth, the fiscal deficit declined only marginally to 1.2 percent of GDP in 2002 . Sizable accounting revisions replaced earlier reported small surpluses with deficits. In 2002, current noninterest expenditures, including for wages, again exceeded budget targets but a larger deficit was avoided by revenues from a tax amnesty (in the context of settling tax arrears for the self employed) and lower-than-budgeted investment spending. The estimated structural deficit (net of asset sales) declined by $1 / 2$ percentage point to 2 percent of GDP. The public debt-to-GDP ratio, at 105 percent of GDP in 2002 , remained one of the highest in the euro area. Amid sizable revenue relief from a tax reform, the 2003 budget targeted a reduction in the fiscal deficit to 0.9 percent of GDP, reflecting lower interest payments and leaving the structural deficit broadly unchanged under the budget's GDP growth assumption (4 percent of GDP). However, the central government cash deficit widened markedly in the first quarter of 2003 , amid strong primary spending growth.

The near-term outlook is subject to large external risks, but preliminary estimates of strong GDP growth in the first quarter of 2003 indicated that growth prospects remain considerably more favorable than in most partner countries. The staff expects that historically low interest rates, EU-financed projects, the 2004 Olympics preparations, and the recent tax reform would support domestic demand, leading to GDP growth of 3.6 percent in 2003 . However, the growth outlook is subject to considerable risks: an extended period of global weakness in the wake of the Iraq war would adversely affect tourist arrivals, while a delayed recovery in major export markets and a further appreciation of the euro would further weaken external demand. With continued strong growth, average inflation is expected to remain broadly unchanged in 2003 .

\section{Executive Board Assessment}

Executive Directors noted that earlier reforms and interest rate declines duning the convergence process preceding Greece's entry into the euro area continue to underpin an extended period of strong economic growth, and that, more recently, some gains have been made on the employment front. At the same time, however, a relatively loose macroeconomic policy mix - combined with a variety of transitory and convergence-related factors-has resulted in widening macroeconomic imbalances, including a large external current account deficit and rapidly rising private sector indebtedness, and the persistence of a substantial inflation differential vis-à-vis the euro area.

Directors agreed that the challenge facing the Greek authorities is to use the opportunity provided for by the present strong economic growth, to address these emerging imbalances and accelerate the structural reforms that will help ensure sustained convergence in living standards to EU levels. This will be achieved through tightening the fiscal stance to reduce the high level of public debt; strengthening financial sector supervision; and accelerating reforms in labor and product markets. 
To ensure a gradual reduction in Greece's external current account deficit and its relatively high external indebtedness, Directors stressed that, in addition to sustained fiscal consolidation, steps will need to be taken to strengthen external competitiveness. Wage moderation will have a key role to play, in this regard, and Directors called on public sector wage agreements to lead by example. They also noted that product market reforms aimed at raising productivity and fostering competition will help strengthen price competitiveness.

Directors urged the authorities to accelerate the pace of fiscal consolidation and to aim for faster progress in reducing the high public debt, in particular given the favorable cyclical and accommodative monetary conditions. They stressed the importance of correcting any budget slippages promptly, and called for a more ambitious, front-loaded fiscal adjustment than is currently envisaged. A number of Directors recommended a strengthening of the structural balance by at least 0.5 percent of GDP per year to help ensure a steady decline in the debt-toGDP ratio to 60 percent.

Directors stressed that public expenditure restraint and prioritization will be key to achieving fiscal consolidation, in particular, in the areas of public sector wages and employment. They welcomed steps to strengthen auditing and expenditure contro! procedures in the broader public sector (including on health care), and encouraged the authorities to proceed with plans for reducing Greece's relatively high military expenditures. Increased disclosure of debtcreating below-the-line transactions and limiting the amount of such transactions to future privatization receipts will also be important to support debt reduction objectives. While welcoming the recent consolidation of public pension funds and steps that will facilitate the establishment of private funds, Directors emphasized that additional steps will be needed at an early stage to address longer-term spending pressures related to population aging.

Directors supported ongoing efforts to improve public sector transparency and efficiency. They saw the planned "Code of Fiscal Stability" as a welcome step toward enhancing public sector accountability, but noted that its effectiveness would depend on tight borrowing limits and strict enforcement. Directors encouraged the authorities to consider the introduction of binding, multiyear expenditure ceilings, and to take further steps to limit the room for discretion and abuse in the civil service. The improved transparency and more equitable distribution of the tax burden that will result from the recent tax reform are welcome, but Directors cautioned that future reform steps will need to condition tax relief on commensurate expenditure savings.

Directors welcomed the Bank of Greece's recent decisions to strengthen provisioning requirements and further upgrade supervisory expertise in the face of evolving financial sector risks. While the level of private sector indebtedness remains low by international standards, they noted that its rapid increase heightens the need for vigilance and readiness to take appropriate steps, especially if banks' capital ratios, which remain well above regulatory minima, were to decline further. They also saw a need for increasing market-based discipline by expanding information disclosure requirements. To address the challenging financial situation in the insurance sector, Directors called for the establishment of a fully independent supervisory agency that would closely coordinate with other financial sector supervisors. Directors encouraged the authorities to undertake an Financial Sector Assessment Program, 
which would allow a broader review of financial sector issues. They welcomed Greece's efforts to combat money laundering and the financing of terrorism.

While employment has begun to increase, following several years of decline, Directors noted that additional efforts remain essential in order to achieve the employment and labor force participation targets of the Lisbon Agenda. They highlighted, in particular, the importance of steps to facilitate labor market entry by women and the young, improve labor market flexibility and job matching, and increase wage differentiation. A number of Directors encouraged the authorities to continue to work with the social partners towards the elimination of catch-up clauses in wage contracts.

Directors commended the authorities for progress on privatization amid difficult market conditions, but emphasized the need for further structural efforts to bolster competition, reduce administrative barriers and improve the business climate to strengthen the foundations for higher foreign investment and strong income growth over the medium-term. Specific priorities include the strengthening of the effectiveness of the Competition Authority and the easing of entry barriers in the electricity sector.

Directors encouraged the authorities to play an active role in liberalizing all imports from the least developed countries, and to sustain their efforts to raise official development assistance.

Directors welcomed the important statistical improvements associated with Greece's subscription to the IMF's Special Data Dissemination Standard. They looked forward to further steps to address remaining significant weaknesses including in the fiscal area.

Public Information Notices (PINs) are issued, (i) at the request of a member country, following the conclusion of the Article IV consultation for countries seeking to make known the views of the IMF to the public. This action is intended to strengthen IMF surveillance over the economic policies of member countries by increasing the transparency of the IMF's assessment of these policies; and (ii) following policy discussions in the Executive Board at the decision of the Board. The Staff Report for the 2003 Article IV Consultation with Greece is also available. 


\section{Greece: Selected Economic Indicators}

\begin{tabular}{|c|c|c|c|c|c|}
\hline & 1999 & 2000 & 2001 & 2002 & 20031 \\
\hline \multicolumn{6}{|l|}{ Real economy (change in percent) } \\
\hline GDP & 3.6 & 4.2 & 4.1 & 4.0 & 3.6 \\
\hline Domestic demand & 2.8 & 3.9 & 3.1 & 3.9 & 3.9 \\
\hline EU harmonized cansumer inflation (period average) & 2.1 & 2.9 & 3.7 & 3.9 & 3.8 \\
\hline Unemployment (in percent) & 11.9 & 11.1 & 10.4 & 8.9 & 9.8 \\
\hline \multicolumn{6}{|l|}{ Public finance (general government, in percent of GDP) } \\
\hline Overall balance & -1.8 & -1.9 & -1.4 & -1.2 & -1.4 \\
\hline Primary balance & 5.4 & 5.1 & 4.9 & 4.3 & 3.9 \\
\hline Structural balance 2 & -2.0 & -2.5 & -2.5 & -2.1 & -2.2 \\
\hline Debt & 105.1 & 106.2 & 107.0 & 104.8 & 100.1 \\
\hline Of which: external debt 3 I & 26.3 & 22.1 & 6.5 & 3.7 & $\ldots$ \\
\hline \multicolumn{6}{|l|}{ Money and credit (end-period, percent change) } \\
\hline Greek contribution to euro area M3 $4 i$ & 5.6 & 17.1 & 7.4 & -1.8 & $\ldots$ \\
\hline Domestic credit & 12.2 & 27.6 & 24.8 & 16.9 & $\cdots$ \\
\hline \multicolumn{6}{|l|}{ Interest rates (year average) } \\
\hline 3-month treasury bill rate & 9.8 & 7.2 & 3.8 & 2.9 & $\ldots$ \\
\hline 12-month treasury bill rate & 8.9 & 6.2 & 4.1 & 3.2 & $\ldots$ \\
\hline \multicolumn{6}{|l|}{ Balance of payments (settlements basis, in percent of GDP) } \\
\hline Trade balance & -14.3 & -17.8 & -16.3 & -16.1 & -16.9 \\
\hline Current account balance (including capital transfers) & -4.0 & -6.8 & -6.2 & -6.1 & -6.9 \\
\hline Foreign exchange reserves (US\$ billions) 51 & 18.1 & 13.4 & 5.1 & 8.1 & $\ldots$ \\
\hline \multicolumn{6}{|l|}{ Exchange rates } \\
\hline Exchange rate reglme & \multicolumn{5}{|c|}{ Euro-area member } \\
\hline Present rate (May 16, 2003) & & & 5 per 1 & & \\
\hline Nominal effective rate $(1995=100) \mathrm{a} /$ & 90.0 & 84.8 & 84.2 & 84.7 & 86.0 \\
\hline Real effective rate (unit labor cost basis; 1995=100) 61 & 103.8 & 100.5 & 101.0 & 104.13 & 106.8 \\
\hline
\end{tabular}

Sources: Data provided by the Greek authcrities; and IMF staff estimates and projections.

1/IMF staff projections, except where indicated otherwise.

2/ For 2001, excludes UMTS revenues equivalent to 0.4 percent of GDP.

3 / From 2001, foreign debt includes only liabilities in non-euro area currencies.

4/ Data pricr to 2000 refer to growth of Greek liquidity measure M4N.

$5 /$ Omlilal reserves declined in 2001 with euro participation, due in lerge part to the redefinition of foreign exchange reserves and the fall in foreign exchange reserve requirements for commercial banks.

$6 /$ Data for 2003 refer to January. 


\section{Statement by Hari Vittas, Alternate Executive Director for Greece May 16, 2003}

\section{Key Points}

- Economic activity continued to grow at a robust rate in 2002, despite the adverse external environment. Short-term prospects are also positive, although the margin of uncertainty has increased.

- The persistence of a sizable external current account deficit and a high inflation differential relative to the euro area are issues of concern, even though they are driven largely by cyclical and other transitory or convergence-related factors.

- Fiscal performance has shown improvement in 2002, albeit more limited than initially intended. Further fiscal consolidation remains an important policy priority.

- The key medium-term challenge is to sustain a high rate of total factor productivity (TFP) growth in order to improve external competitiveness, lower dependence on foreign savings and accelerate real convergence. Meeting this challenge will hinge mainly on successfui implementation of the structural reform agenda.

- Important steps have been taken to contain financial sector risks in the wake of the recent surge in private-sector credit.

My authorities wish to express their appreciation to Mr. Krueger and his team for the high quality of their work and for their constructive policy advice. As is evident from the staff report, this year's consultation discussions did not bring up any major differences of views between the authorities and the staff either on the economic outlook or the key issues on the policy agenda. Nevertheless, the discussions have been fruitful and the staff's analytical work and its recommendations, both of which are attracting some publicity in Greece, are helping to build support for required, but yet to be implemented, policy adjustments.

\section{Sustained investment-led growth...}

The Greek economy weathered the global slowdown in 2002 reasonably well, as the weakness of export demand was offset by the continued buoyancy of residential construction and private consumption, and strong growth in investment spending by private and public enterprises. The sustained expansion in economic activity, which benefited from large EU community support funds and easy domestic monetary conditions, was reflected in a modest improvement in the labor market. Total employment grew by about 1 percent in 2002 and the unemployment rate fell to 9.7 percent by the last quarter of the year. The labor force 
participation ratio also rose by about 1 percentage point in 2002 , suggesting that recent measures to improve the functioning of the labor market are beginning to bear fruit.

... is accompanied by signs of strains on resources.

Consumer prices (HICP basis) continued to increase faster in Greece than on average in the euro area, with the differential rising to 1.7 percent in 2002 . According to estimates by the Bank of Greece, the widening of the differential can be attributed for the most part to special factors, such as the greater sensitivity of the Greek economy to the rise in the pricc of oil, as well as the comparatively high incidence of weather-related increases in agricultural prices in early 2002. Core inflation was about the same as in 2001 and the gap relative to the euro area average narrowed to 1.4 percent. Even so, the gap remains higher than can be explained by Balassa-Samuelson effects and the comparatively advanced cyclical position of the Greek economy. Although significant market-liberalization initiatives have been taken in recent years, the authorities recognize that competition in some segments of the Greek economy remains inadequate, exacerbating the impact of transitory price shocks and fostering rentseeking behavior. Inadequate competition and buoyant demand conditions in some key sectors have facilitated an increase in profit margins in 2002. By contrast, the rise in unit wage costs, while somewhat higher than in trade partner countries, was lower than the increase in prices, casting doubt on whether it can be viewed (as in the staff report) as the principal cause of the relatively high rate of inflation.

The external current account deficit was sustained at a high level in 2002 , for the third year in a row. It is worth stressing that the deficit is primarily a reflection of the high and rapidly rising level of investment, including business investment, rather than a decline in national saving. It may therefore be seen as a feature of the "catching up" process that should lead in due course not only to convergence in living standards but also to the correction of the external imbalance as investment augments the country's productive capacity and (net) export potential. It is also worth pointing out that the deficit has tended to narrow over the past couple of years, albeit slightly, despite (a) a much higher rate of growth in Greece than in its main trade partners; and (b) a significant reduction in net transfer receipts from abroad (which may be related in part to the sharp reversal of migration flows over the past decade). This suggests that some improvement in the underlying extemal position may already be under way.

Notwithstanding these considerations, my authorities do not share the view that the current account deficit is a matter for "benign neglect". Its size points at present to the persistence of strains on resources, which need to be brought under control. Moreover, the deficit leads to a steady deterioration in the net investment position, which increases vulncrability to future shocks. The authorities recognize that the correction of the imbalance will require, beyond the elimination of any excess demand pressures, a gradual improvenent in external competitiveness (as measured by the evolution of relative unit labor costs). While wage "moderation" is essential in this regard, the real challenge for the policy makers is to cnsure that the required improvement in competitiveness comes about as a result of a comparatively superior TFP growth in Greece rather than through wage compression. 


\section{Good prospects for growth, although uncertainties have increased.}

The official forecast, which calls for real GDP growth of 3.8 percent in 2003 and only a slight abatement of price pressures, is predicated on continued strong growth of domestic demand. Fixed capital formation is expected to remain a key driving force, buoyed by the accelerated disbursement of EU funds, high business investment (partly in anticipation of the 2004 Olympic Games) and continued strong growth in residential construction. Consumer spending is also projected to rise markedly, on the strength of robust growth in personal pretax incomes and a decline in taxation. By contrast, the foreign sector is expected to make a small negative contribution to output growth.

Since the preparation of the forecast, estimates of global economic growth have been marked town. Also, prospects for the tourism sector became more uncertain in the first few months of the year, although expectations have improved again after the resolution of the Iraq crisis. These developments raise the question of whether the official forecast for growth is still feasible. While it is difficult to provide a clear-cut response, the authorities believe that any shortfall is likely to be small and note that, according to (just released) preliminary national accounts data, growth in first quarter of 2003 accelerated to 4.3 percent (year-on-year). They also point out that the outlook for inflation has recently improved as a result of the decline in the price of oil and the further strengthening of the euro in the exchange markets. It is noteworthy that in April the ycar-on-year rate of increase in consumer prices (HICP basis) fell sharply to 3.3 percent.

\section{Fiscal consolidation progresses, albeit sluggishly.}

The strengthening of the public finances continued in 2002, with the general government deficit declining somewhat (to 1.2 percent of GDP) and the public debt ratio falling more noticeably (to about 105 percent of GDP). Accounting revisions to fiscal data were also implemented, in agreement with Eurostat, resulting in a significant improvement in the transparency and accuracy of the fiscal accounts, including a substantial reduction in the size of stock-flow adjustments.

Consolidation is set to continue in 2003 and over the medium term, in accordance with Greece's updated stability program, which was reviewed by the ECOFDN Council last January. Under the program, the general government balance is projected to turn to a surplus of 0.6 percent of GDP by 2006 , with the public debt ratio falling quite rapidly to about 87 percent of GDP. The authorities recognize that tight expenditure control, including in particular of the wage bill, will be required to meet these targets. They are confident that the fiscal stability code will greatly improve discipline at all levels of government, but are also considering the feasibility of introducing binding multi-year expenditure norms, as has been

\footnotetext{
${ }^{1}$ However, the accounting revisions also had the (less salutary) side-effect of demonstrating that the celebrations, at the time of last year's Article IV consultation, for the two fiscal "milestones" that Greece was thought to have reached (a surplus in the general government accounts and a debt ratio of less than 100 percent) were...somewhat premature.
} 
recommended by both the ECOFIN Council and the staff. Other recommendations by the Council, calling inter alia for a larger and more front-loaded fiscal adjustment, are curtently being considered by the Government.

\section{Reforms continue, even if at an uneven pace.}

The Government has continued to attach high priority to the implementation of its reform agenda. In some important areas, however, reforms fell short of initial intentions as compromises were made in the interest of preserving social cohesion. The most positive developments since the last consultation include the continued fairly rapid privatization of public enterprises, notwithstanding adverse stock market conditions, the initiation of a major reform of the tax system, the deregulation of coastal shipping and the adoption of a series of measures to improve corporatc governance. In addition, a significant reform of the pension system was undertaken. Although this was not as far-reaching as might be desirable, given the anticipated aging of the population, the rcform has placed the pension system on a sounder footing and, by reducing fragmentation, it has established conditions that should facilitate additional changes in due course.

Looking forward, the authoritics intend to sustain, and to the extent possible accelerate, the process of strengthening competitive pressures in the economy, including through further reforms of product and labor markets. These are essential to contain inflationary pressures and to foster TFP growth, thereby facilitating real convergence and reducing reliance on foreign savings.

\section{Increased attention to financial sector risks.}

Entry into EMU has contributed to the recent rapid growth in private sector credit. It is recognized that this development has increased the financial system's exposure to risks. Although the banks are well capitalized and profitable, the authoritics have taken action to raise provisioning and disclosure requirements and have strengthened their capacity for effective supervision, while also emphasizing the need for prudent lending policics. The authorities stand ready to take further action, if need be, and are also actively considering steps to improve the supervision of other intermediaries and strengthen coordination among the various supervisory entities.

\section{Other Issues}

Following significant improvements in the timeliness, coverage and quality of its statistics, Greece has recently become a subscriber to the SDDS. Efforts to address remaining weaknesses will continue. Concerning ODA, which has risen markedly in recent years, the authorities are committed to the EU goal of raising it to at least 0.39 percent of GDP by 2006 . 